\title{
1
}

Prepared in cooperation with the Tillamook Estuaries Partnership

\section{Water-Quality Conditions and Suspended-Sediment Transport in the Wilson and Trask Rivers, Northwestern Oregon, Water Years 2012-14}

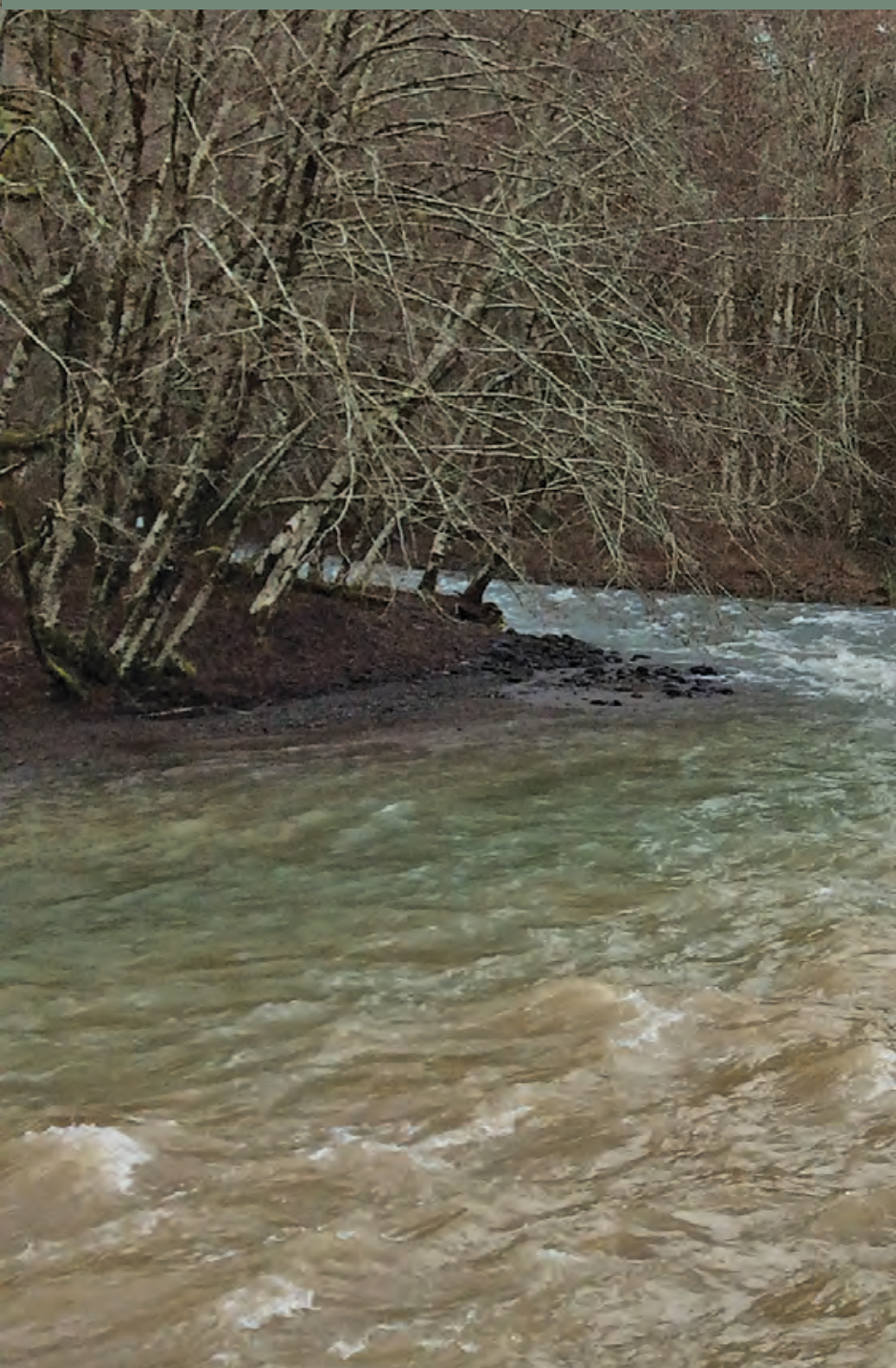

Scientific Investigations Report 2015-5109

U.S. Department of the interior U.S. Geological Survey 
Cover: Photograph showing Wilson River during storm in February 2014. Photograph by Steven Sobieszczyk, U.S. Geological Survey. 


\section{Water-Quality Conditions and Suspended- Sediment Transport in the Wilson and Trask Rivers, Northwestern Oregon, Water Years 2012-14}

By Steven Sobieszczyk, Heather M. Bragg, and Mark A. Uhrich

Prepared in cooperation with the Tillamook Estuaries Partnership

Scientific Investigations Report 2015-5109 


\title{
U.S. Department of the Interior SALLY JEWELL, Secretary
}

\section{U.S. Geological Survey Suzette M. Kimball, Acting Director}

\author{
U.S. Geological Survey, Reston, Virginia: 2015
}

For more information on the USGS - the Federal source for science about the Earth, its natural and living resources, natural hazards, and the environment—visit http://www.usgs.gov or call 1-888-ASK-USGS.

For an overview of USGS information products, including maps, imagery, and publications, visit http://www.usgs.gov/pubprod/.

Any use of trade, firm, or product names is for descriptive purposes only and does not imply endorsement by the U.S. Government.

Although this information product, for the most part, is in the public domain, it also may contain copyrighted materials as noted in the text. Permission to reproduce copyrighted items must be secured from the copyright owner.

Suggested citation:

Sobieszczyk, Steven, Bragg, H.M., and Uhrich, M.A., 2015, Water-quality conditions and suspended-sediment transport in the Wilson and Trask Rivers, northwestern Oregon, water years 2012-14: U.S. Geological Survey Scientific Investigations Report 2015-5109, 32 p., http://dx.doi.org/10.3133/sir20155109.

ISSN 2328-0328 (online) 


\section{Contents}

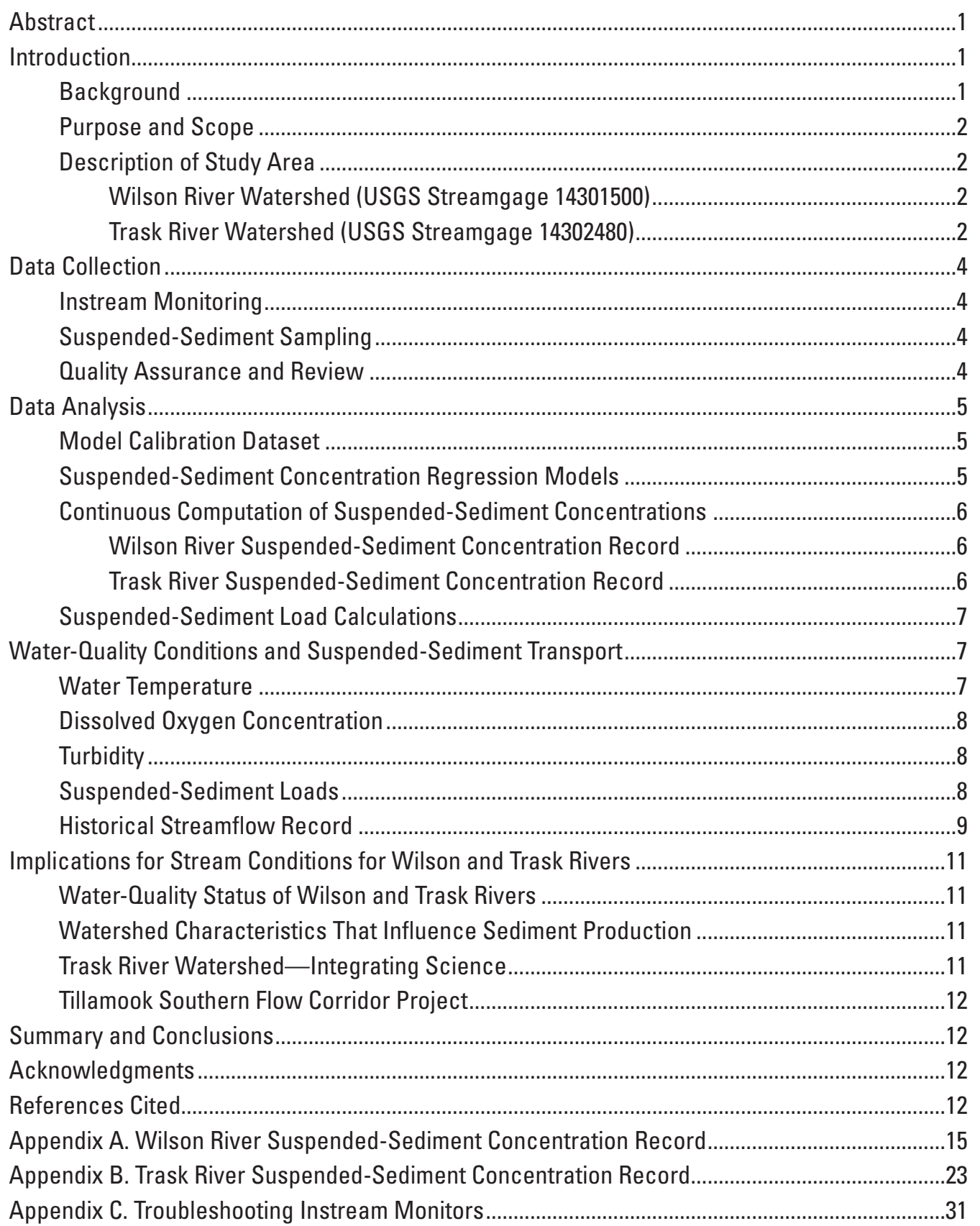




\section{Figures}

1. Map showing location of the Wilson and Trask Rivers, northwestern Oregon

2. Graphs showing instantaneous turbidity duration curves for suspended-sediment samples collected at Wilson River and Trask River streamgage locations, northwestern Oregon, water years 2012-2014

3. Time-series graphs showing 7-day average maximum water temperature for the Wilson and Trask Rivers, northwestern Oregon, water years 2012-2014

4. Time-series graph showing dissolved oxygen data for the Wilson and Trask Rivers, northwestern Oregon, water years 2012-2014

5. Graphs showing daily median turbidity data for the Wilson and Trask Rivers, Oregon, water years 2012-2014

6. Graphs showing monthly suspended-sediment loads for the Wilson and Trask Rivers, northwestern Oregon, water years 2012-2014.

7. Graphs showing peak annual streamflow for the period of record for the Wilson and Trask Rivers, northwestern Oregon

\section{Tables}

1. Streamflow and water-quality monitoring information for the Wilson and Trask Rivers, northwestern Oregon.

2. Water-quality parameters measured at the Wilson and Trask Rivers, northwestern Oregon, water years 2012-2014

3. Suspended-sediment concentration regression models for the Wilson and Trask Rivers, northwestern Oregon.

4. Annual suspended-sediment loads for the Wilson and Trask Rivers, northwestern Oregon, water years 2012-2014 


\section{Conversion Factors}

Inch/Pound to International System of Units

\begin{tabular}{lcl}
\hline \multicolumn{1}{c}{ Multiply } & By & \multicolumn{1}{c}{ To obtain } \\
\hline foot $(\mathrm{ft})$ & Length & \\
mile (mi) & 0.3048 & meter $(\mathrm{m})$ \\
& 1.609 & kilometer $(\mathrm{km})$ \\
\hline square mile $\left(\mathrm{mi}^{2}\right)$ & Area & \\
square mile $\left(\mathrm{mi}^{2}\right)$ & 2.590 & square kilometer $\left(\mathrm{km}^{2}\right)$ \\
\hline & 640 & acre \\
\hline gallon (gal) & Volume & \\
cubic foot $\left(\mathrm{ft}^{3}\right)$ & 3.785 & liter $(\mathrm{L})$ \\
\hline & 0.02832 & cubic meter $\left(\mathrm{m}^{3}\right)$ \\
\hline cubic foot per second $\left(\mathrm{ft}{ }^{3} / \mathrm{s}\right)$ & Flow Rate & \\
\hline & 0.02832 & cubic meter per second $\left(\mathrm{m}^{3} \mathrm{~s}\right)$ \\
\hline ton, short $(2,000 \mathrm{lb})$ & Mass & \\
ton per day per square mile $\left[(\right.$ ton $\left./ \mathrm{d}) / \mathrm{mi}^{2}\right]$ & 0.9072 & megagram $(\mathrm{Mg})$ \\
& 0.3503 & megagram per day per square kilometer \\
\hline
\end{tabular}

Temperature in degrees Celsius $\left({ }^{\circ} \mathrm{C}\right)$ may be converted to degrees Fahrenheit $\left({ }^{\circ} \mathrm{F}\right)$ as follows:

$$
{ }^{\circ} \mathrm{F}=\left(1.8 x^{\circ} \mathrm{C}\right)+32 .
$$

\section{Supplemental Information}

Specific conductance is given in microsiemens per centimeter at 25 degrees Celsius $(\mu \mathrm{S} / \mathrm{cm}$ at $\left.25^{\circ} \mathrm{C}\right)$.

Suspended-sediment concentrations are reported in milligrams per liter (mg/L). Sediment loads are reported in tons.

Turbidity is given in formazin nephelometric units.

Dissolved oxygen is reported in milligrams per liter $(\mathrm{mg} / \mathrm{L})$.

A water year is the 12-month period from October 1 through September 30 of the following calendar year. The water year is designated by the calendar year in which it ends. For example, water year 2008 is the period from October 1, 2007, through September 30, 2008. 


\section{Datums}

Vertical coordinate information is referenced to the National Geodetic Vertical Datum of 1929 (NGVD 29).

Horizontal coordinate information is referenced to Oregon Lambert (HARN) North American Datum of 1983 (NAD 83).

Elevation, as used in this report, refers to distance above the vertical datum.

\section{Abbreviations and Acronyms}

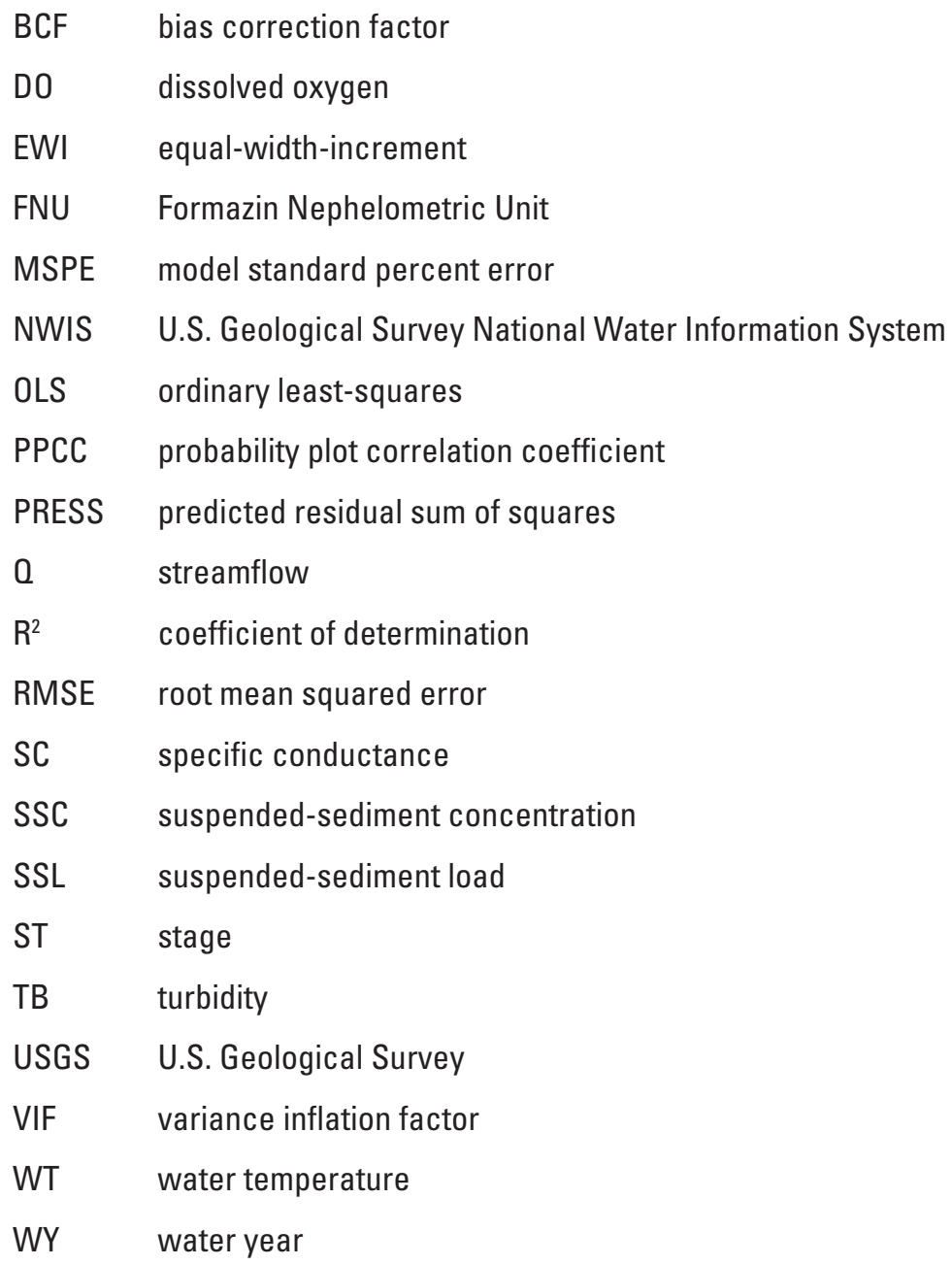




\title{
Water-Quality Conditions and Suspended-Sediment Transport in the Wilson and Trask Rivers, Northwestern Oregon, Water Years 2012-14
}

\author{
By Steven Sobieszczyk, Heather M. Bragg, and Mark A. Uhrich
}

\section{Abstract}

In October 2011, the U.S. Geological Survey began investigating and monitoring water-quality conditions and suspended-sediment transport in the Wilson and Trask Rivers, northwestern Oregon. Water temperature, specific conductance, turbidity, and dissolved oxygen were measured every 15-30 minutes in both streams using real-time instream water-quality monitors. In conjunction with the monitoring effort, suspended-sediment samples were collected and analyzed to model the amount of suspended sediment being transported by each river. Over the course of the 3-year study, which ended in September 2014, nearly 600,000 tons (t) of suspended-sediment material entered Tillamook Bay from these two tributaries.

Each year of the study, the Wilson River transported between 80,300 and 240,000 t of suspended sediment, while the Trask River contributed between 28,200 and 69,900 t. The suspended-sediment loads observed during the study were relatively small because streamflow conditions were routinely lower than normal between October 2011 and September 2014. Only one storm had a recurrence interval between a 2- and 5-year event. Every other storm produced streamflows equivalent to what would be classified as a 1- or 2-year event. Because most sediment moves during high flows, the lack of heavy rainfall and elevated streamflows muted any high sediment loads.

Along with assessing suspended-sediment transport, the U.S. Geological Survey also monitored instream water quality. This monitoring was used to track instream conditions and relate them to water temperature, dissolved oxygen, and sedimentation issues for the Wilson and Trask Rivers. Stream temperatures in the Wilson and Trask Rivers exceeded the temperature standard for cold-water habitat. Water temperatures at both streams exceeded the standard for more than 30 percent of the year, as stream temperatures increased above the seasonal 13 degrees Celsius $\left({ }^{\circ} \mathrm{C}\right.$ ) (seasonal core cold-water habitat) and $16^{\circ} \mathrm{C}$ (salmon and steelhead [Oncorhynchus mykiss] spawning) thresholds. Conversely, dissolved oxygen concentrations rarely decreased to less than the absolute water-quality criterion of 8 milligrams per liter for cold-water streams.

Results from this study will provide resource managers insight into the seasonality of water-quality conditions and the extent of suspended-sediment transport in the Wilson and Trask Rivers. The data are useful for establishing a baseline and for maintaining best-use land management practices and possibly for aiding in prioritization of restoration actions for both rivers and their respective watersheds.

\section{Introduction}

\section{Background}

Water-quality impairments in the Tillamook Bay watershed (fig. 1) threaten native fish species, such as coho salmon (Oncorhynchus kisutch) and cutthroat trout (Oncorhynchus clarkii). Recent studies (Tillamook Estuaries Partnership, 1999; Oregon Department of Environmental Quality, 2001; Demeter Design, 2009; Johnson and Drake, 2011; Reiter and others, 2013) have identified the primary water-related issues for Tillamook Bay and its tributaries as (1) warming stream temperatures, (2) increased sedimentation and associated point and nonpoint source pollution, such as nutrients and toxics, (3) low dissolved oxygen concentrations, and (4) altered or modified channels. Each of these conditions greatly affects the overall health and quality of aquatic habitats. 
Over the last few decades, landscape changes such as large forest fires, removal of riparian vegetation, and engineered channel modifications have greatly degraded the water quality of many of Oregon's northern coastal streams (Oregon Department of Environmental Quality, 2001). These degraded conditions have led to increases in fine-sediment transport, scouring of stream channels, decreases in suitable streambed habitat, and increases in stream temperatures resulting from increased exposure to direct sunlight (Demeter Design, 2009). High stream temperatures are especially problematic in summer and autumn, when above-average water temperatures can stress spawning fish populations (Oregon Department of Environmental Quality, 2001). In October 2011, the U.S. Geological Survey (USGS), in cooperation with the Tillamook Estuaries Partnership, began investigating and monitoring water-quality conditions and suspended-sediment transport in the Wilson and Trask Rivers, northwestern Oregon.

\section{Purpose and Scope}

The purpose of this report is to summarize suspendedsediment transport and continuously monitored water-quality data for the Wilson (USGS streamgage 14301500) and Trask (USGS streamgage 14302480) Rivers. This study addressed a deficiency in long-term monitoring of local streams by establishing a water-quality and suspended-sediment monitoring network for two major tributaries to Tillamook Bay. This study provided water-resource managers with continuous real-time data of water temperature, specific conductance, turbidity, and dissolved oxygen concentrations. USGS researchers provided estimates of suspended-sediment loads for the two rivers during the 3-year study period (October 1, 2011-September 30, 2014; water years 2012-14). This study did not address issues of Escherichia coli, fecal coliform bacteria, or other contaminants that are common water-quality issues in the two streams and in Tillamook Bay. Archived data can be accessed through the USGS National Water Information System database (U.S. Geological Survey, 2015a, 2015b).

Along with monitoring instream conditions and providing estimates for suspended sediment, specific objectives also included:

- Publishing site-specific regression models that estimate suspended-sediment concentrations using continuous turbidity and (or) streamflow data as surrogates;

- Evaluating stream conditions for water temperature, dissolved oxygen, turbidity, and sedimentation; and

- Evaluating future effects of sediment on potential downstream restoration projects, such as the Southern Flow Corridor Project (Northwest Hydraulic Consultants, 2011).

\section{Description of Study Area}

Studies in Tillamook Bay (Oregon Department of Environmental Quality, 2001; Mico and Mico, 2009; Tillamook Estuaries Partnership, 2010; Johnson and Drake, 2011) have provided detailed basin setting and ecological characterization of the Wilson River watershed (Sullivan and others, 2001; Duck Creek Associates, 2008) and the Trask River watershed (Follansbee and Stark, 1998; Snyder and others, 2003). For this study, the combined drainage area for the two monitoring sites accounts for approximately 60 percent of the total contributing area to Tillamook Bay. Typical rainfall for the Wilson and Trask River watersheds is about 123 in/yr (Follansbee and Stark, 1998).

\section{Wilson River Watershed (USGS Streamgage 14301500)}

The Wilson River begins in the Coast Range of northwestern Oregon, approximately $45 \mathrm{mi}$ west of Tillamook Bay (fig. 1). Although the river flows into the bay, the Wilson River streamgage is $10.2 \mathrm{mi}$ upstream of the delta (table 1). From that monitoring location, the river drains $161 \mathrm{mi}^{2}$ of mostly forested land (about 80 percent of the basin; Risly and others, 2008). Terrain in the watershed varies from peak elevations of higher than 3,620 ft in the Coast Range to a valley floor where elevations are at or just above sea level. Most of the watershed is within the Tillamook State Forest. In the upper watershed, the Wilson River flows through wide gravel-rich areas and through stable confined basalt gorges (Jones and others, 2012). Near the streamflow gage along the lower parts of the watershed, the Wilson River meanders as a wide channel with abundant large gravel bars.

\section{Trask River Watershed (USGS Streamgage 14302480)}

Similar to the Wilson River, the Trask River headwaters originate along the Coast Range in the Tillamook State Forest. Geographically, the Trask River watershed is the next Tillamook Bay tributary south of the Wilson River (fig. 1); therefore, they share very similar physiographic and geologic settings. For this study, water quality was monitored on the Trask River at USGS streamgage 14302480 (table 1). From this location, the river drains $156 \mathrm{mi}^{2}$ of mostly forested land (about 78 percent of the basin; Risly and others, 2008). Unlike the Wilson River, the Trask River sampling occurred at a different location than the monitoring. Suspended-sediment samples were collected at the Long Prairie Road Bridge, 4.0 mi downstream of the streamgage. This sampling site was used because there was not a cableway located at the streamgaging site (fig. 1). 


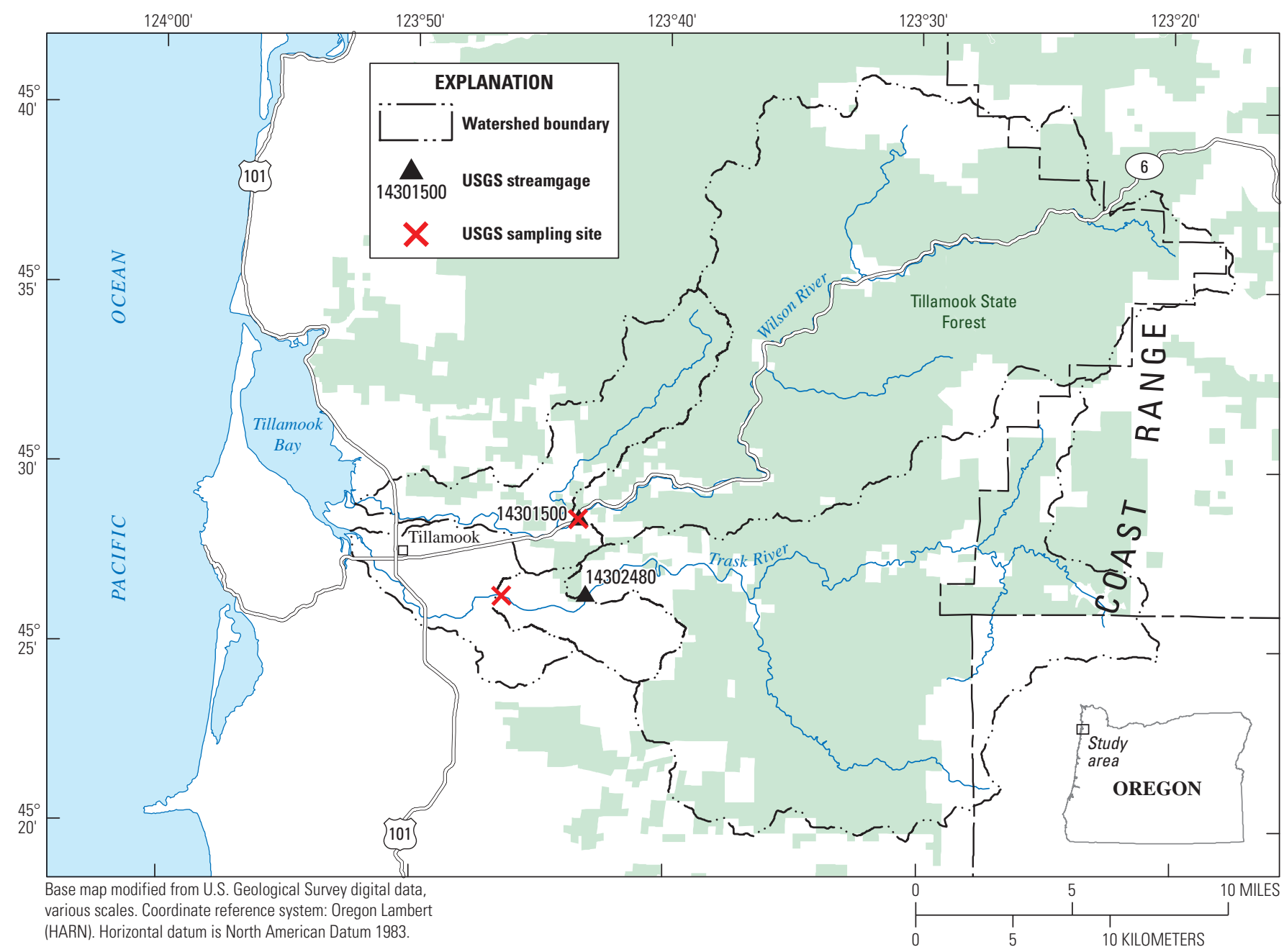

Figure 1. Location of the Wilson and Trask Rivers, northwestern Oregon.

Table 1. Streamflow and water-quality monitoring information for the Wilson and Trask Rivers, northwestern Oregon.

[Parameters: DO, dissolved oxygen concentration; SC, specific conductance; TB, turbidity; WT, water temperature. Abbreviations: USGS, U.S. Geological Survey. $\mathrm{mi}^{2}$, square miles]

\begin{tabular}{|c|c|c|c|c|c|c|c|}
\hline \multirow{2}{*}{$\begin{array}{c}\text { USGS } \\
\text { streamgage } \\
\text { No. }\end{array}$} & \multirow[b]{2}{*}{ USGS streamgage name } & \multirow{2}{*}{$\begin{array}{c}\text { Drainage } \\
\text { basin area } \\
\left(\mathrm{mi}^{2}\right)\end{array}$} & \multicolumn{3}{|c|}{ Water-quality record } & \multicolumn{2}{|c|}{ Streamflow record } \\
\hline & & & Parameters & $\begin{array}{l}\text { Period of record } \\
\text { (water year) }\end{array}$ & $\begin{array}{c}\text { Years of } \\
\text { record }\end{array}$ & $\begin{array}{l}\text { Period of record } \\
\text { (water year) }\end{array}$ & $\begin{array}{l}\text { Years of } \\
\text { record }\end{array}$ \\
\hline 14301500 & Wilson River near Tillamook & 161 & DO, SC, TB, WT & 2012-2014 & 3 & $\begin{array}{l}\text { 1915-1916, } \\
\text { 1931-present }\end{array}$ & 85 \\
\hline 14302480 & $\begin{array}{l}\text { Trask River above Cedar Creek, } \\
\text { near Tillamook }\end{array}$ & 156 & DO, SC, TB, WT & 2012-2014 & 3 & 1996-present & 18 \\
\hline
\end{tabular}




\section{Data Collection}

Data were collected using a combination of instream water-quality monitoring and suspended-sediment sampling. More details about the sediment collection and processing are provided in appendixes A and B.

\section{Instream Monitoring}

Water temperature, specific conductance, and turbidity data were collected in near-real-time at the Wilson and Trask River streamgaging locations between October 2011 and September 2014 (water years 2012-14) (table 2). Dissolved oxygen concentration also was monitored at both rivers; however, it was only measured during the warmer months (May-June through October). Water-quality conditions were monitored using YSI, Inc. 6920-V2 multiparameter instruments. Sensors were checked and calibrated monthly using protocols described by Wagner and others (2006). Streamflow was computed from stage using USGS protocols (Rantz and others, 1982; Sauer and Turnipseed, 2010; Turnipseed and Sauer, 2010). At the Wilson River streamgage, all parameters were recorded at 15 -minute intervals. At the Trask River streamgage, parameters were logged at 30-minute intervals from October 1, 2011 to May 22, 2012, after which the interval was changed to 15 minutes. All data were recorded on Sutron Satlink datalogger-transmitters and uploaded to the online National Water Information System database every 2 hours.

\section{Suspended-Sediment Sampling}

USGS personnel collected suspended-sediment samples during calibration-site visits and during storm-related events. An equal-width-increment (EWI) method (Edwards and Glysson, 1999; U.S. Geological Survey, 2006) was used to collect cross-sectional, depth-integrated samples from a bankoperated cableway at the Wilson River site. EWI samples were collected from the Long Prairie Road Bridge downstream of the Trask River site. All samples were analyzed at the USGS Cascade Volcano Observatory sediment laboratory based on procedures described in Guy (1969) for suspended-sediment concentration in milligrams per liter (mg/L), and most were analyzed for percent silt and clay (fine sediment), as reported in percentage of samples finer than $63 \mu \mathrm{m}$.

During the study, 93 EWI samples were collected, 45 at the Wilson River and 48 at the Trask River. Suspendedsediment samples were collected over nearly the entire range of hydrologic conditions for both rivers. Figure 2 shows the distribution of sample collection over the range and duration of instantaneous turbidity values at each streamgage. Most samples were collected during the less-frequent high turbidity events. These conditions were targeted for sampling because they were indicative of the greatest potential suspendedsediment transport. Only a few samples were collected when turbidity was less than 5.0 Formazin Nephelometric Units (FNU), when suspended-sediment transport conditions were greatly reduced.

\section{Quality Assurance and Review}

For quality assurance, sequential replicate sample pairs were compared individually to validate the reproducibility of the sampling method (Rasmussen and others, 2009). An ordinary least-squares (OLS) linear regression analysis was completed between the sample pairs at both monitoring sites. The OLS regression was useful because it formulated an equation that most closely approximated the sampled data. The results showed that the suspended-sediment concentration values for all sample pairs at both sites were highly correlated (coefficient of determination $\left[\mathrm{R}^{2}\right]=0.98$ ) and close to a $1: 1$ relation (slope $=1.01$ ) over a range of $1-1,730 \mathrm{mg} / \mathrm{L}$.

Table 2. Water-quality parameters measured at the Wilson and Trask Rivers, northwestern Oregon, water years 2012-2014.

[Units: $\mathrm{ft} / \mathrm{s}$, cubic feet per second; ft, feet; ${ }^{\circ} \mathrm{C}$, degrees Celsius; $\mu \mathrm{S} / \mathrm{cm}$, microsiemens per centimeter; FNU, Formazin Nephelometric Unit; mg/L, milligrams per liter]

\begin{tabular}{lll}
\hline \multicolumn{1}{c}{ Parameter } & \multicolumn{1}{c}{ Units } & Description \\
\hline Streamflow (Q) & $\mathrm{ft}^{3} / \mathrm{s}$ & Stream velocity over a given area \\
Stage (ST) & $\mathrm{ft}$ & Height of water based off a known datum \\
Water temperature (WT) & ${ }^{\circ} \mathrm{C}$ & \\
Specific conductance (SC) & $\mu \mathrm{S} / \mathrm{cm}$ & Water, unfiltered, microsiemens per centimeter at $25^{\circ} \mathrm{C}$ \\
Turbidity (TB) & $\mathrm{FNU}$ & $\begin{array}{c}\text { Monochrome near infra-red LED light, 780-900 nanometers, detection angle } 90 \pm 2.5 \\
\text { degrees }\end{array}$ \\
Dissolved oxygen concentration (DO) & $\mathrm{mg} / \mathrm{L}$ & Optical dissolved oxygen concentration \\
\hline
\end{tabular}




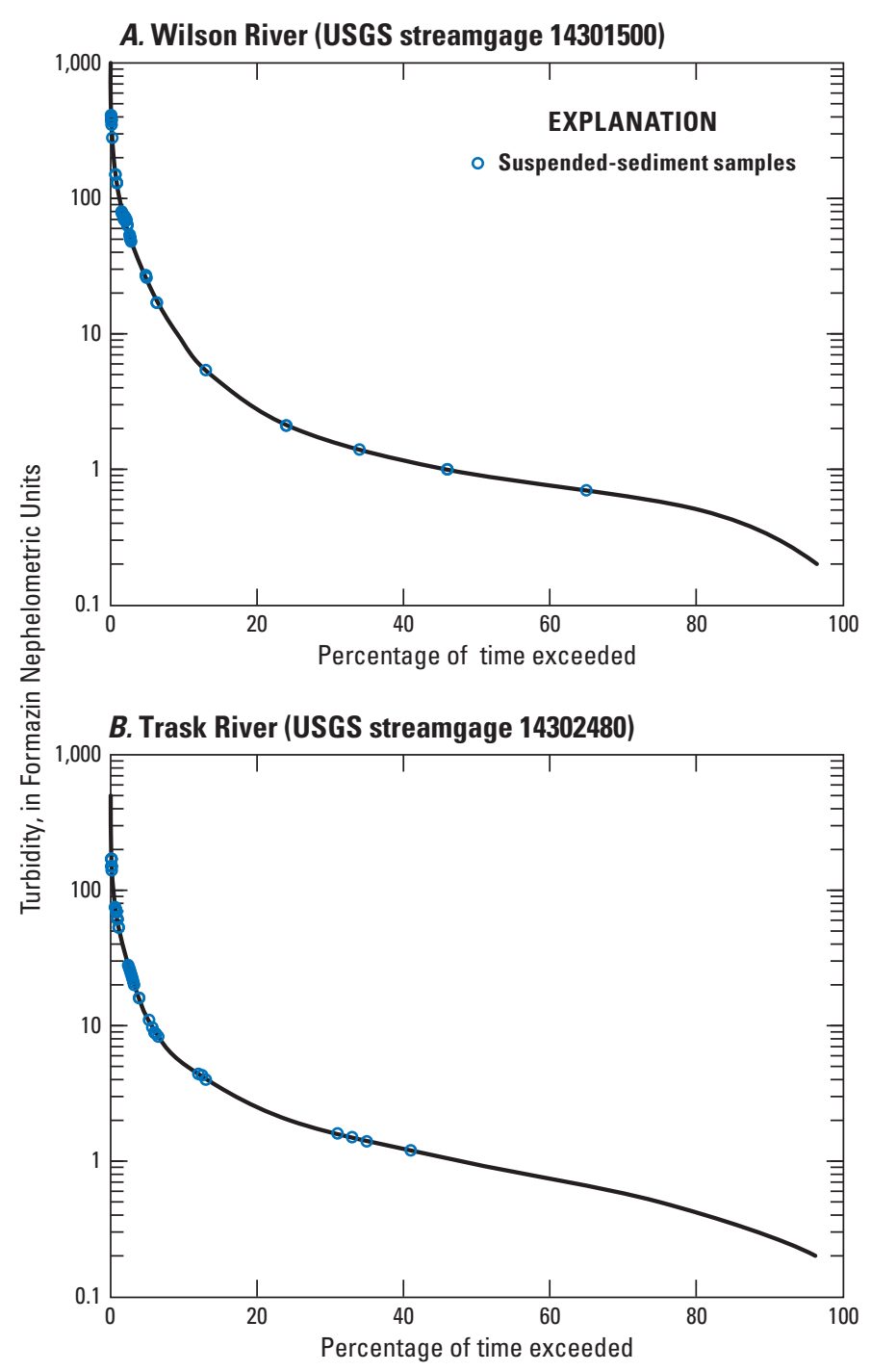

Figure 2. Instantaneous turbidity duration curves for suspended-sediment samples collected at $(A)$ Wilson River and $(B)$ Trask River streamgage locations, northwestern Oregon, water years 2012-2014.

\section{Data Analysis}

\section{Model Calibration Dataset}

Each suspended-sediment concentration (SSC) sample was assigned a discrete turbidity and streamflow value from the continuous water-quality monitoring record (15- or 30-minute data). For each sample, turbidity was computed as an average of the instantaneous sensor readings, beginning with the value logged immediately before the start time of the sample collection and ending with the value logged immediately after the end time. Because EWI samples could take as long as an hour to complete, there were usually 3-4 turbidity readings recorded during the sampling period. The streamflow was interpolated between the instantaneous values to the mean time of the sample collection (see appendixes A and $\mathrm{B}$ for more detail).

The collection times for the Trask River EWI samples were adjusted to account for the distance between the streamgage and the sampling site. The time-of-travel correction ranged from 55 to 150 minutes, depending on the streamflow at the time of sample collection (see appendix B for more detail). The time differences were subtracted from the actual beginning, mean, and ending sample times before assigning discrete turbidity and streamflow values to the samples. No obvious outliers were identified in the initial graphical analysis of the sample datasets. However, three EWI samples collected in November 2011 at the Trask River had to be excluded from analysis because the associated turbidity values were removed because of sensor fouling. When EWI sample pairs were collected, the associated SSC, turbidity, and streamflow values of the individual samples were averaged over the sampling period and used for the regression analysis. As a result, the final model calibration dataset included 25 sampling events for the Wilson River and 23 for the Trask River. Additional information concerning the development of the regression models and computation of the continuous SSC record is available in appendixes A and B.

\section{Suspended-Sediment Concentration Regression Models}

Using the final sample datasets, OLS regression analyses were completed with the SSC sample data and the instream turbidity and streamflow data for both the Wilson and Trask Rivers. All calculations were computed with a standardized USGS spreadsheet tool designed specifically for surrogate regressions for SSC (Rasmussen and Gray, 2014) using methods described in Rasmussen and others (2009). Turbidity and streamflow were evaluated individually using simple linear regressions and together using multiple linear regressions. They also were evaluated using $\log _{10}$-transformed and untransformed data, as possible independent variables. At both sites, turbidity and streamflow were too highly correlated to use both parameters, so single linear regressions were chosen.

Several summary statistics recommended by Rasmussen and others (2009) were computed to evaluate the appropriateness of the regression models (table 3). These included the coefficient of determination $\left(\mathrm{R}^{2}\right)$, which was used to explain variance of predicted versus observed; the root mean squared error (RMSE), which was converted to the upper and lower model standard percent errors (MSPE); the probability plot correlation coefficient (PPCC), which was used to indicate improved normality of the residuals by data transformations; and the predicted residual sum of squares (PRESS), which was used to check the fit of observations that were not used in the model. Residual plots for evaluating variance, normality, homoscedasticity, and curvature are provided in appendixes $\mathrm{A}$ and $\mathrm{B}$. 
Table 3. Suspended-sediment concentration regression models for the Wilson and Trask Rivers, northwestern Oregon.

[Regression model equation: SSC, suspended-sediment concentration; TB, turbidity. BCF: bias correction factor. $\mathbf{R}^{2}$ : coefficient of determination. M SPE : model standard prediction error. PPCC : probability plot correlation coefficient. PR E SS: predicted residual sum of squares. USGS, U.S. Geological Survey]

\begin{tabular}{|c|c|c|c|c|c|c|c|}
\hline $\begin{array}{c}\text { USGS } \\
\text { streamgage } \\
\text { No. }\end{array}$ & USGS streamgage name & Regression model equation & BCF & $\begin{array}{c}\text { Adjusted } \\
\mathbf{R}^{2}\end{array}$ & $\begin{array}{c}\text { MSPE } \\
\text { (percent) }\end{array}$ & PPCC & PRESS \\
\hline 14301500 & Wilson River near Tillamook & $\log _{10} \mathrm{SSC}=0.361+1.05 \log _{10} \mathrm{~TB}$ & 1.11 & 0.95 & -36.4 & 0.97 & 1.17 \\
\hline 14302480 & $\begin{array}{l}\text { Trask River above Cedar Creek, } \\
\text { near Tillamook }\end{array}$ & $\log _{10} \mathrm{SSC}=0.331+1.06 \log _{10} \mathrm{~TB}$ & 1.06 & 0.96 & $\begin{array}{r}42.6 \\
-29.9\end{array}$ & 0.94 & 0.60 \\
\hline
\end{tabular}

The $\log _{10}$-transformed models using turbidity as the explanatory variable were chosen for both sites based on residual plots, adjusted $\mathrm{R}^{2}$, MSPE, PPCC, and PRESS statistics. The final form of the regression model was:

$$
\log _{10} \mathrm{SSC}=\mathrm{b}+\mathrm{a} * \log _{10} \mathrm{~TB}
$$

where

SSC is suspended-sediment concentration, in milligrams per liter;

TB is turbidity, in Formazin Nephelometric Units; and

$\mathrm{a}$ and $\mathrm{b}$ are the slope and $\mathrm{y}$-intercept coefficients, respectively, obtained by the OLS regression analysis.

The logarithmic transformation and subsequent conversion back to original form introduced a known bias, which was addressed with a bias correction factor (BCF) as outlined in Helsel and Hirsch (2002).

\section{Continuous Computation of Suspended- Sediment Concentrations}

A complete SSC record was needed to compute the annual suspended-sediment loads (SSL) for the Wilson and Trask Rivers. When turbidity values were missing from the records, instantaneous SSC values were estimated by different methods, depending on streamflow conditions. For the simplest method, SSC values were estimated by interpolating between the model-computed SSC values immediately before and after the missing turbidity data. This method worked well for short time periods when streamflow conditions were steady or when turbidity was consistently increasing or decreasing. For longer periods, or during changing streamflow conditions, SSC was estimated by developing an OLS regression model of SSC using streamflow, rather than turbidity, as an explanatory variable. This method worked best when SSC and streamflow were strongly correlated. Prediction intervals were calculated for each of the regression models to provide error estimates for the continuous SSC. For each computed SSC, the upper and lower predictions were calculated at 90-percent confidence intervals (appendixes A and B).

\section{Wilson River Suspended-Sediment Concentration Record}

For most of the 3-year period, continuous SSC at the Wilson River was computed using the $\log _{10}$-transformed turbidity regression model and 15-minute turbidity data. Simple interpolations were used to estimate 11.0, 6.9, and 11.5 percent of the annual records for water years 2012-14, respectively. Most of these estimates were during lowflow, low-turbidity, and low-sediment transport conditions when there were issues with algal biofouling of the optical turbidity sensor (appendix C). During water years 2012 and 2013, several storms produced turbidity values greater than the maximum (410 FNU) included in the model calibration dataset. Therefore, the computed SSCs were designated as "estimated" in the SSC record. These estimated values comprised 0.05 and 0.14 percent of the annual records for water years 2012 and 2013, respectively.

\section{Trask River Suspended-Sediment Concentration Record}

For the Trask River, continuous SSCs were computed using a similar $\log _{10}$-transformed turbidity regression model, but with both 30 - or 15-minute turbidity data. Simple interpolations were used to estimate $7.3,4.3$, and 15.8 percent of the annual records for water years 2012-14, respectively. Similarly, most of these estimates were during low-flow and low-turbidity conditions. As with the Wilson River, several storms produced turbidity values for the Trask River greater than the maximum $170 \mathrm{FNU}$ included in the model calibration dataset. For these periods, the computed SSCs were described as “estimated," as well, and comprised 0.02, 0.07, and 0.13 percent, respectively, of the annual records for water years 2012-14. Excessive leaf compaction and siltation during a storm in November 2011 resulted in the need to remove 12 days of instream turbidity data. SSC values during this period were computed with a separate streamflow OLS regression model. The resulting computed SSC values were considered “estimated" and comprised 2.2 percent of the annual SSC record for water year 2012. 


\section{Suspended-Sediment Load Calculations}

The computed and estimated SSC values and corresponding streamflow data were used to calculate continuous SSL for the Wilson and Trask Rivers. The instantaneous SSL values were used to calculate daily SSL, which were then summed to calculate monthly and annual SSL. SSL was calculated as:

$$
\mathrm{SSL}=\mathrm{SSC} * \mathrm{Q}^{*} \mathrm{C}
$$

where

SSL is suspended-sediment load, in pounds per second,

SSC is suspended-sediment concentration, in milligrams per liter,

Q is streamflow, in cubic feet per second, and

c is the conversion coefficient to convert values to pounds per second (equal to 0.00006242).

The instantaneous SSL values were multiplied by the appropriate time interval and summed to compute total daily SSL. The monthly and annual SSL values were calculated by summing the daily SSL values and converting to tons.

\section{Water-Quality Conditions and Suspended-Sediment Transport}

\section{Water Temperature}

Between water years 2012 and 2014, there were long periods when the Wilson and Trask Rivers did not meet the water temperature standard (fig. 3) established for coldwater habitat streams in Oregon (Oregon Department of Environmental Quality, 2005a, 2005b, 2014). Each year, between July and October, stream temperatures increased to at least $20^{\circ} \mathrm{C}$ in both streams, well above the 7-day average maximum temperature criterion of $16^{\circ} \mathrm{C}$ for summer seasonal periods or the $13{ }^{\circ} \mathrm{C}$ criterion for the remainder of the year (Oregon Department of Environmental Quality, 2014). High stream temperatures were likely exacerbated by the relatively low baseflow conditions observed each summer during the study period. Each year, 35 percent of the Wilson River temperature readings exceeded the established threshold, and about 33 percent of Trask River temperature readings exceeded the criteria.

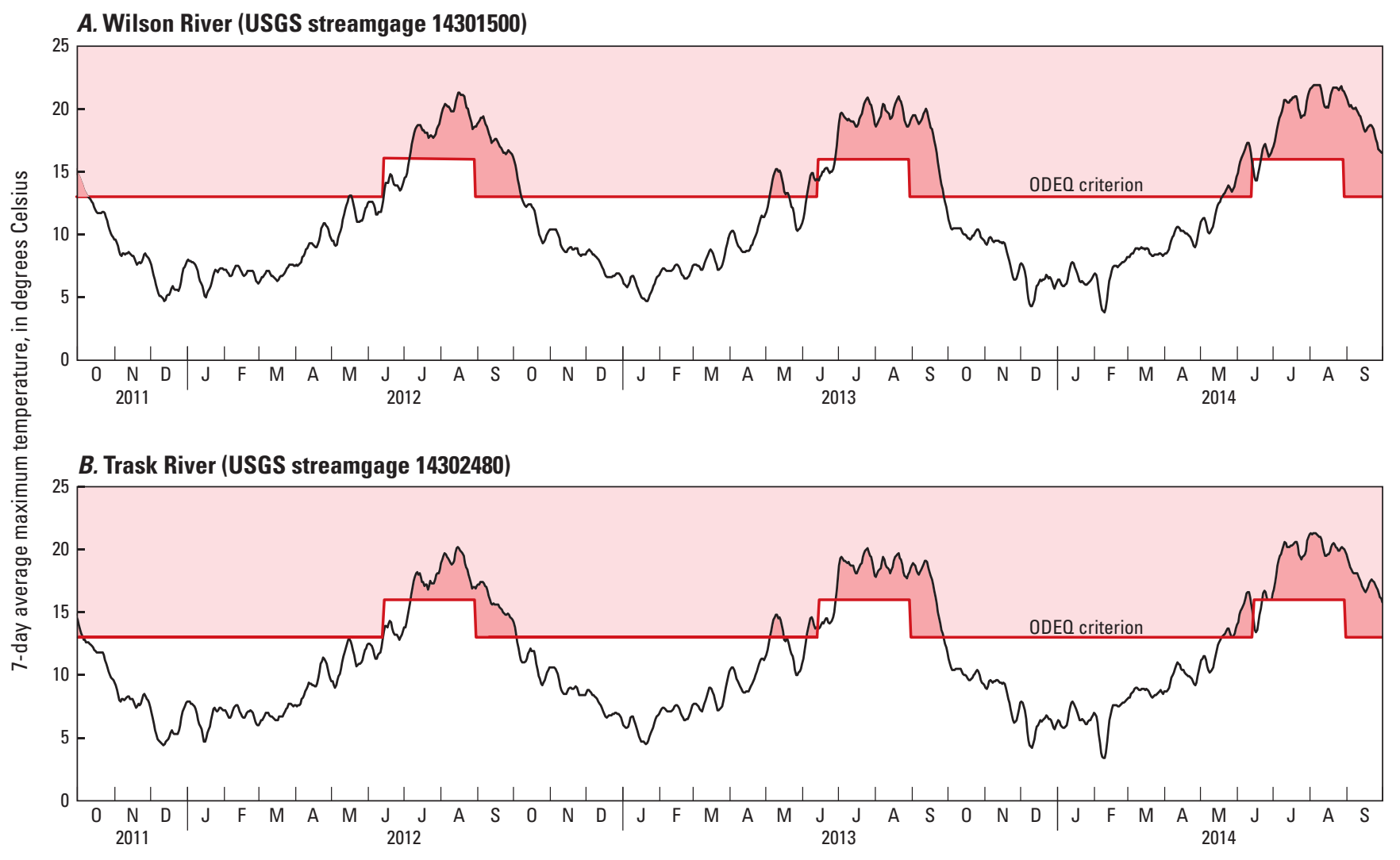

Figure 3. 7-day average maximum water temperature for the Wilson and Trask Rivers, northwestern Oregon, water years 2012-2014. ODEQ Criterion line corresponds to Oregon Department of Environmental Quality water temperature criterion for seasonal core cold-water habitat $\left(13^{\circ} \mathrm{C}\right)$ and salmon and steelhead spawning $\left(16^{\circ} \mathrm{C}\right)$ designated streams. Shaded areas represent times when ODEO Criterion was not met. 


\section{Dissolved Oxygen Concentration}

Dissolved oxygen concentrations in the Wilson and Trask Rivers (fig. 4) consistently met the minimum $8.0 \mathrm{mg} / \mathrm{L}$ criterion for cold-water habitat streams in Oregon (Oregon Department of Environmental Quality, 2005a, 2005b, 2014). Dissolved oxygen concentrations in the Trask River never decreased to less than the $8.0 \mathrm{mg} / \mathrm{L}$ criterion. Dissolved oxygen concentrations in the Wilson River remained greater than the threshold for all but a small fraction of time in the summer of 2014, when a few isolated readings decreased to 7.9 and $7.8 \mathrm{mg} / \mathrm{L}$. There were 16 days with instantaneous readings less than $8.0 \mathrm{mg} / \mathrm{L}$. Concentrations decreased to less than the criterion for less than 1 hour on 8 of those days. The longest period of concentrations less than $8.0 \mathrm{mg} / \mathrm{L}$ was on July 20, 2014, when readings did not meet the established criterion for about 6 hours.

\section{Turbidity}

Turbidity is an important water-quality indicator of sediment issues and can act as a surrogate for fine sediment transport (Bragg and Uhrich, 2010). The current Oregon Department of Environmental Quality standard for turbidity indicates that "turbidity causing activities" should not increase downstream turbidity by more than 10 percent (Oregon Department of Environmental Quality, 2014). However, it does not detail criteria for baseline stream conditions using turbidity as a water-quality impairment metric.

The turbidity record for the Wilson and Trask Rivers for water years 2012-14 demonstrates periods of intermittently turbid water and increased suspended-sediment transport (fig. 5). However, given the previous history of flooding (National Weather Service, 2014) and the potential for future flooding, the turbidity observed during the study was likely low compared to each river's potential. Between the two rivers, the Wilson River was consistently more turbid than the Trask River during storms, largely because of the higher streamflow conditions. During the study period, the highest daily median turbidity at both sites was recorded in water year 2012 (fig. 5).

\section{Suspended-Sediment Loads}

Daily, monthly, and annual SSL were computed for each monitored watershed. Mean annual streamflows also were referenced to provide context for the annual SSL values. An estimated 597,000 $t$ of suspended sediment entered Tillamook Bay during water years 2012-14. For both the Wilson and Trask Rivers, annual SSL was highest during water year 2012 (240,000 and 69,900 t, respectively; table 4). Mean annual streamflow also was highest during water year 2012. At the Wilson River streamgage, most of the annual SSL in water year 2012 occurred from November 2011 to January 2012 (65 percent of the total annual SSL), but the highest single month was March 2012 (34 percent; fig. 6). Similarly, for the Trask River, the SSL in November 2011 through January 2012 comprised 58 percent and March 2012 comprised 36 percent of the annual SSL in water year 2012.

About one-half the annual SSL was produced in water year 2013 compared to water year 2012 for both rivers. Mean streamflow also was lower for the Wilson and Trask Rivers in water year 2013 compared to the previous year, as well. The only significant autumn or winter storm during water year 2013 occurred in November 2012, although there were several smaller storms in December 2012 that added to the annual SSL. November and December 2012 accounted for 70 percent of the annual SSL at the Wilson River and 73 percent at the Trask River. A late summer/early autumn storm in September 2013 contributed to the annual SSL at the end of water year 2013.

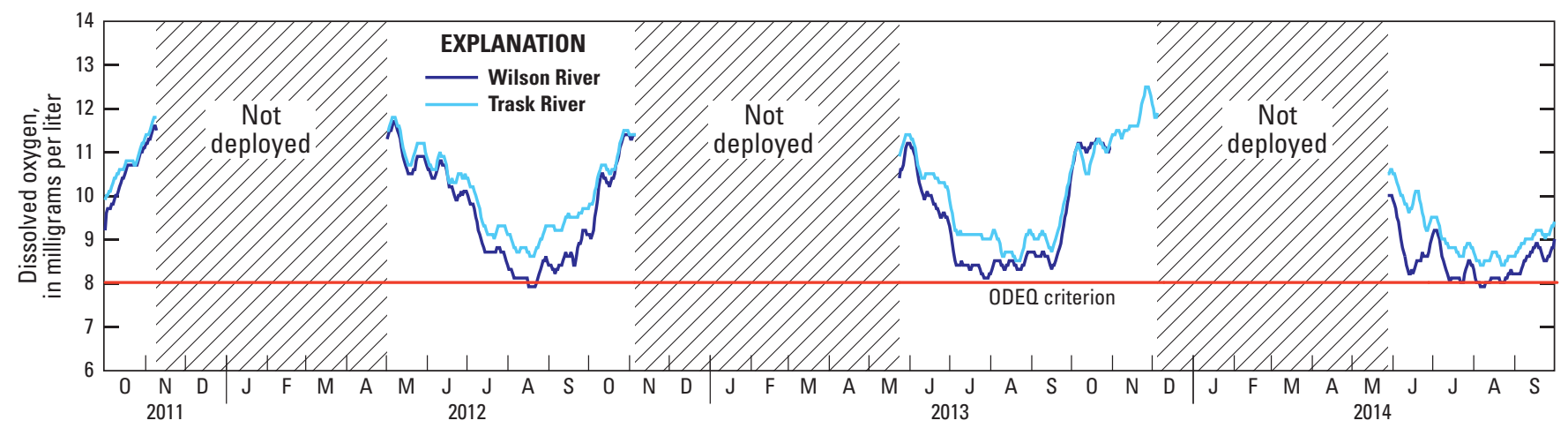

Figure 4. Dissolved oxygen data for the Wilson and Trask Rivers, northwestern Oregon, water years 2012-2014. 0DE0 Criterion line corresponds to Oregon Department of Environmental Quality dissolved oxygen criterion for cold-water streams based on 30-day mean minimum daily concentration ( 8.0 milligrams per liter). 


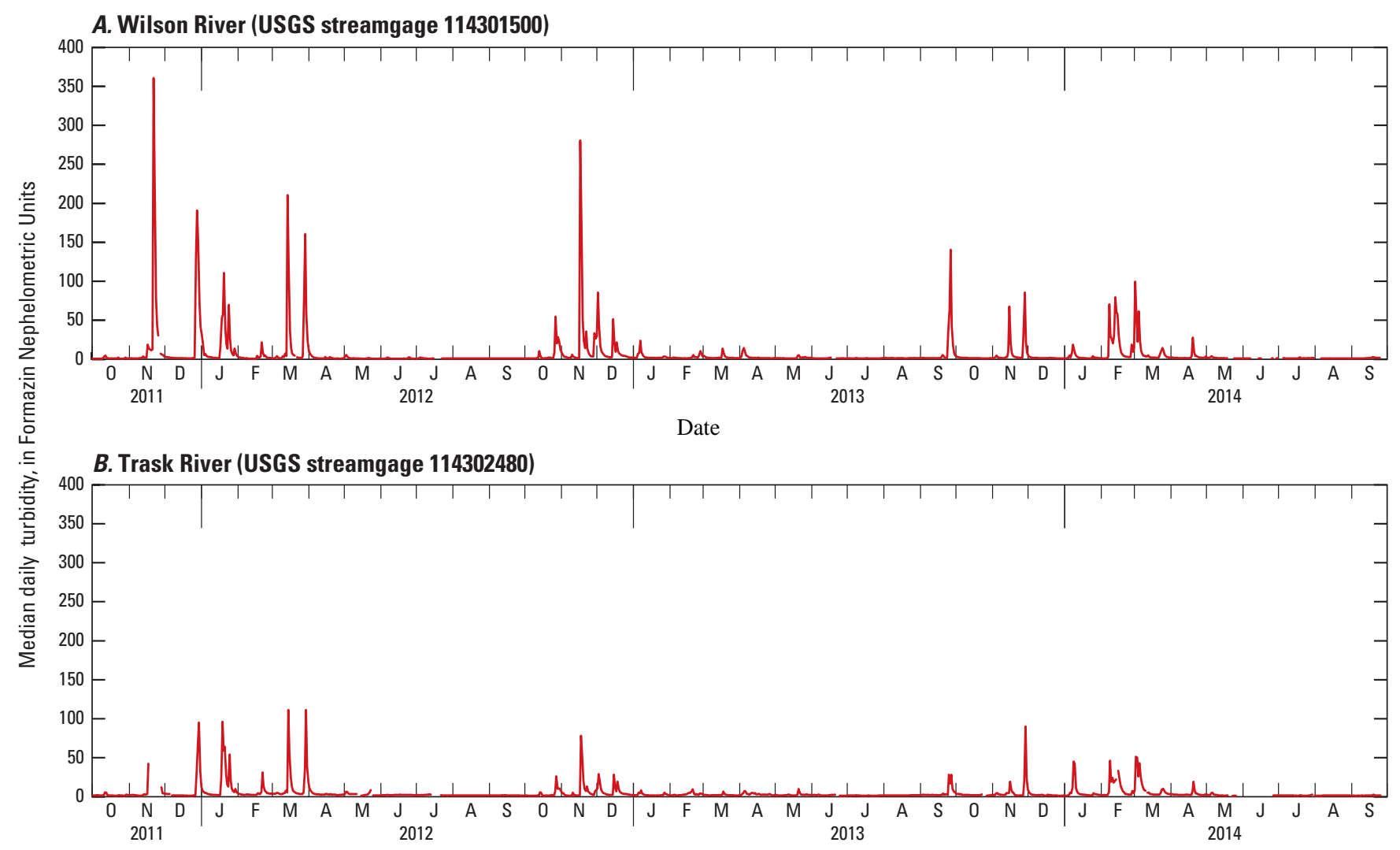

Figure 5. Daily median turbidity data for the Wilson and Trask Rivers, Oregon, water years 2012-2014.

Table 4. Annual suspended-sediment loads for the Wilson and Trask Rivers, northwestern Oregon, water years 2012-2014.

[USGS, U.S. Geological Survey; WY, water year]

\begin{tabular}{llrrr}
\hline \multirow{2}{*}{$\begin{array}{c}\text { USGS } \\
\text { station No. }\end{array}$} & \multicolumn{1}{c}{ USGS station name } & \multicolumn{3}{c}{ Annual suspended-sediment load (tons) } \\
\cline { 3 - 5 } 14301500 & Wilson River near Tillamook & WY2012 & WY2013 & WY2014 \\
\hline 14302480 & Trask River above Cedar Creek, near Tillamook & 69,900 & 28,200 & 49,300 \\
\hline
\end{tabular}

Annual SSL for the Wilson River was lower in water year 2014 than for the two prior water years. There were no significant autumn or winter storms, so only the minor storms in February and March supplied any sizable amount of sediment to the annual SSL (combined 67 percent). At the Trask River, annual SSL for water year 2014 ranked between the other two water years. The storms in December 2013 contributed more to the annual SSL at the Trask River than at the Wilson River (30 and 17 percent, respectively). SSL in February (32 percent) and March (25 percent) were comparable at the Trask River. Both locations had their lowest mean annual streamflow during water year 2014.

\section{Historical Streamflow Record}

During the study, weather conditions were calm and peak annual streamflows were minimal compared to prior years. Between the autumn of 2011 and the autumn of 2014, peak streamflows in neither the Wilson nor Trask Rivers exceeded a 5-year recurrence interval, and the Trask River streamflow never exceeded a 2-year event (fig. 7). Because heavy rainfall and high streamflow are required to transport large sediment loads, the SSL calculated for this study did not represent the full sediment transport capacity by either system. Therefore, the regression models developed for this study better reflect 

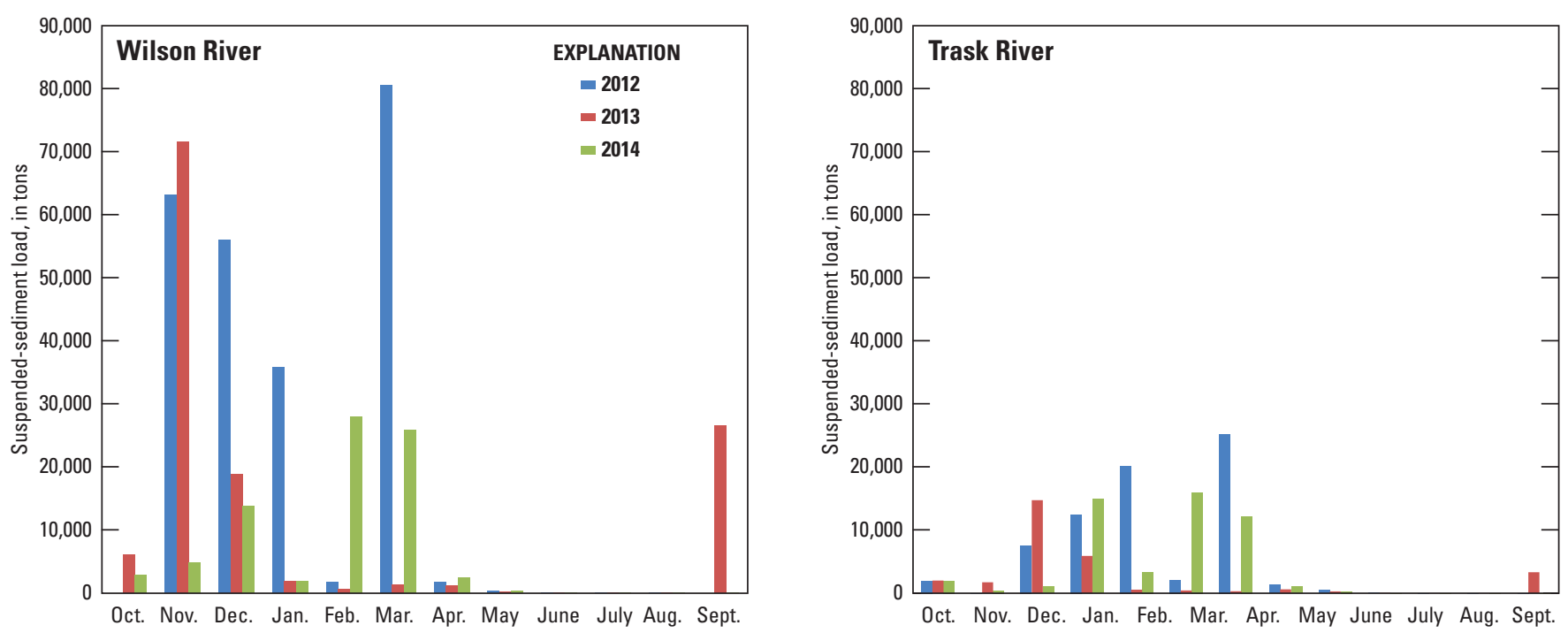

Figure 6. Monthly suspended-sediment loads for the Wilson and Trask Rivers, northwestern Oregon, water years 2012-2014.

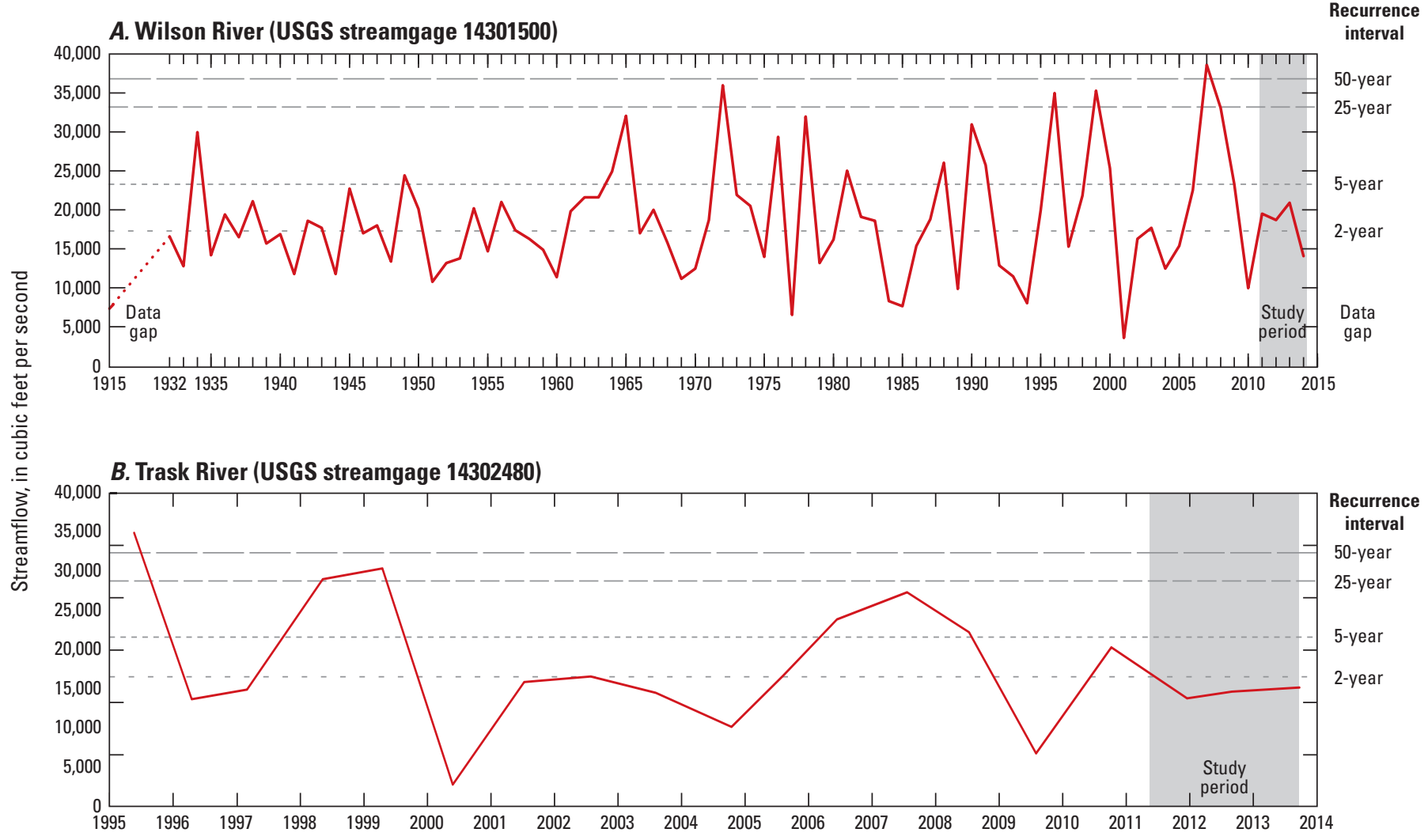

Figure 7. Peak annual streamflow for the period of record for the $(A)$ Wilson and $(B)$ Trask Rivers, northwestern Oregon. Shaded area corresponds to 3-year study period. Dashed lines indicate streamflow recurrence intervals for 2-year, 5-year, 25-year, and 50-year type events (Cooper, 2005). 
the lower range and magnitude of potential SSL in the Wilson and Trask Rivers. Given the consistency of the streamflow conditions during the study, the models presented do provide a strong baseline for SSL transported by a typical storm in a given year. To retain validity, the regression models should be revisited every few years to ensure that discrete sediment sources, such as landslides or changing channel conditions, have not altered the previously observed sediment transport conditions.

\section{Implications for Stream Conditions for Wilson and Trask Rivers}

\section{Water-Quality Status of Wilson and Trask Rivers}

The Oregon Department of Environmental Quality (2012) has listed segments of the Wilson and Trask Rivers for a variety of constituent impairments, including water temperature, dissolved oxygen, E. coli, fecal coliform, and other toxics and pollutants. Between water years 2012-14, the USGS continuously monitored water temperature, specific conductance, turbidity, and dissolved oxygen in the Wilson and Trask Rivers. Both rivers showed periods when established criterion were not met for water temperature. For example, water temperature routinely exceeded the temperature threshold each summer and remained so for the months leading into the autumn. Temperature in the Wilson and Trask Rivers exceeded the cold-water-habitat temperature criterion for about one-third of the year. Both streams did maintain compliance with the dissolved oxygen standard, as neither showed prolonged periods of low dissolved oxygen. However, summer conditions in both streams were near the dissolved oxygen threshold set by the State, including a brief period of slightly less than the $8.0 \mathrm{mg} / \mathrm{L}$ criterion for the Wilson River for parts of a few days in summer 2014. Sampling for other water-quality impairments, such as E. coli and nutrients, was beyond the scope of this project.

Along with monitoring water-quality conditions, the USGS sampled and modeled suspended-sediment transport. Sedimentation was identified as one of the greatest basin-wide concerns for Tillamook Bay and has been a focal point for monitoring and management in the past (Tillamook Estuaries Partnership, 1999; Johnson and Drake, 2011). Although many North Coast rivers are considered as being in good condition, some water-quality constituents like biochemical oxygen demand (BOD) and phosphorus have shown a downward trend in recent years (Johnson and Drake, 2011). During this study, normal to less than normal precipitation limited the amount of erosion and subsequent suspended-sediment transport throughout the area. The annual transported totals were likely only a fraction of the material that would be transported during prolonged high streamflow or flooding conditions.

\section{Watershed Characteristics That Influence Sediment Production}

Historically, sedimentation issues have influenced much of the resource planning and land management practices in the Tillamook Bay area (Duck Creek Associates, 2008; Johnson and Drake, 2011). As such, there is a continuing desire to better understand sediment sources and transport. Currently, there are no defined criteria because there is a lack of sufficient sediment data (Oregon Department of Environmental Quality, 2012). Data from this study can be used to supplement previous datasets from the State.

Sediment affects many things, including fish populations, water-quality impairment, contaminant transport, efficacy of restoration projects, and shipping and navigation. Previous studies (Duck Creek Associates, 2008) have demonstrated that undisturbed soil erosion in the Wilson and Trask River watersheds does not produce excessive sedimentation because native soils are sufficiently permeable. However, issues arise when soils become compacted or when drainage from roads augments sediment production. Thus, potential processes for increased sediment production in the Tillamook Bay watershed would include runoff from logging roads, storm-driven debris flows, erosion of freshly harvested timber plots, and other disruptive land use and development practices (Follansbee and Stark, 1998; Komar and others, 2004; Duck Creek Associates, 2008; Arismendi and others, 2013; Hatten and others, 2013). Therefore, any effort to impede excessive sedimentation and limit sediment transport relates directly to the reduction of soil disruptions in the Wilson and Trask River watersheds.

\section{Trask River Watershed—Integrating Science}

The Trask River watershed is heavily studied because resource agencies, universities, and timber companies are interested in how the basin is managed. In any area where landscape disturbance may occur, such as with active logging, there is always a potential for impacts to stream health. Recent studies (Arismendi and others, 2013) have begun to analyze what impact forest practices have on turbidity, SSC, and SSL. Early results indicate a possible increase in turbidity and SSC from roads used to access the new timber areas. In addition to assessing sediment, other studies like Reiter and others (2013) have explored the effect canopy shading and other thermal processes have on stream temperatures and how conditions may change because of changing climate or continued landscape alterations. Linking upstream landscape activity and water quality to lower watershed conditions would be a valuable next step for integrating science and better understanding stream functions in the Trask River. 


\section{Tillamook Southern Flow Corridor Project}

One aspect of ecosystem health that benefits from stream monitoring is local restoration projects. At the confluence of the Wilson and Trask Rivers near Tillamook Bay, there is a proposed plan to reduce flood damage and restore habitat along the Tillamook Southern Flow Corridor (Federal Emergency Management Agency, 2014). The current proposal has undergone an environmental impact assessment and five restoration alternatives have been proposed for the area. The favored alternative focuses on the removal of 7-10 mi of levees to allow flood waters to flow across the project area, restoring 526 acres of mostly farmland back to tidal wetlands (Northwest Hydraulic Consultants, 2011). Monitoring SSL on the Wilson and Trask Rivers can help planners determine how much new material will enter the project area, when it will be entering, and how it might affect fluvial and tidal flow dynamics of the restored area. Long-term data collection also helps identify any temporal trends in water temperature or dissolved oxygen, components necessary for maintaining a healthy aquatic habitat.

\section{Summary and Conclusions}

The U.S. Geological Survey (USGS) investigated and monitored water-quality conditions and suspended-sediment transport in the Wilson and Trask Rivers, northwestern Oregon. The study established a water-quality and suspendedsediment monitoring network for the two rivers, which are major tributaries to Tillamook Bay. The purpose of the study was to provide water-resource managers with continuous real-time water temperature, specific conductance, turbidity, and dissolved oxygen data for the Wilson and Trask Rivers. In addition, USGS researchers provided estimates of suspendedsediment loads for the two rivers during a 3-year study period (October 2011-September 2014; water years 2012-14).

Four main conclusions can be drawn from this USGS monitoring and modeling effort for the Wilson and Trask Rivers:

1. During years when conditions were typical (no drought or flooding), water temperature did not meet established criterion for cold-water habitat. These conditions will likely be exacerbated during drought years or during months with periods of prolonged hot weather.

2. During the study, dissolved oxygen generally met the criterion for migrating or spawning salmonids. Given the standard set by the State of Oregon, there were very few instances during the study when dissolved oxygen concentrations decreased to less than the established threshold.

3. Suspended-sediment transport likely remains an issue to fish populations, restoration efforts, and even navigation; however, given the average rainfall observed during the study, low streamflow conditions did not mobilize and transport significant amounts of sediment to Tillamook Bay. Nonetheless, baseline characterization did provide context for expected suspended-sediment loads in a given year.

4. Instream monitoring provides data to assist land and resource managers make informed decisions. For example in this study, water temperature was shown to still be a potential concern for spawning and migrating fish. As restoration efforts continue in the Wilson and Trask Rivers, monitoring can be instrumental in the management of stream temperature and sedimentation.

\section{Acknowledgments}

We thank York Johnson from the Tillamook Estuaries Partnership and Oregon Department of Environmental Quality and members of the Oregon Watershed Enhancement Board for their vision, support, and funding for this research. We thank Chauncey Anderson (U.S. Geological Survey) for his guidance and oversight. We thank U.S. Geological Survey employees Amy Brooks, Cassandra Smith, Mary Janet, Stewart Rounds, Jami Goldman, John Williams, and David Piatt for their assistance and resources that helped keep everything running smoothly. Lastly, we thank Leo Adams for his responsiveness and tireless efforts in helping to keep the Trask River water-quality monitor up and running.

\section{References Cited}

Arismendi, Ivan, Groom, J.D., Johnson, S.L., Reiter, Maryanne, Dent, Liz, Argerich, Alba, and Skaugset, A.E., 2013, Suspended sediment concentrations and turbidity responses from contemporary road crossings in the Trask River watershed: Corvallis, Oregon State University, Department of Fisheries and Wildlife, accessed March 2015, at http://watershedsresearch.org/assets/reports/WRC_ Arismendi_Trask\%20road_2013_S1.pdf.

Bragg, H.M., and Uhrich, M.A., 2010, Suspended-sediment budget for the North Santiam River basin, Oregon, water years 2005-08: U.S. Geological Survey Scientific Investigations Report 2010-5038, 26 p., http://pubs.usgs. gov/sir/2010/5038/.

Cooper, R.M., 2005, Estimation of peak discharges for rural, unregulated streams in Western Oregon: U.S. Geological Survey Scientific Investigations Report 2005-5116, 134 p., http://pubs.usgs.gov/sir/2005/5116/.

Demeter Design, 2009, Tillamook Bay watershed sediment and physical habitat assessment: Demeter Design, Prepared for the Tillamook Estuaries Partnership, 154 p. 
Duck Creek Associates, Inc., 2008, Wilson River Watershed Analysis: Duck Creek Associates, Inc., Prepared for Oregon Department of Forestry, 632 p., accessed December 2014, at http://www.oregon.gov/odf/pages/state_forests/watershed. aspx.

Edwards, T.K., and Glysson, G.D., 1999, Field methods for measurement of fluvial sediment: U.S. Geological Survey Techniques of Water-Resources Investigations, book 3, chap. C2, 89 p., http://pubs.usgs.gov/twri/twri3-c2/.

Federal Emergency Management Agency, 2014, Tillamook southern flow corridor project: FEMA Environmental Impact Statement, accessed March 2012, at http:// southernfloweis.org.

Follansbee, Bruce, and Stark, Ann, 1998, Trask watershed assessment: Tillamook Bay National Estuary Project, 26 p.

Guy, H.P., 1969, Laboratory theory and methods for sediment analysis: U.S. Geological Survey Techniques of WaterResources Investigations, book 5, chap. C1, 58 p., http:// pubs.usgs.gov/twri/twri5c1/.

Hatten, Jeff, Johnson, Sherri, Li, Judy, and Argerich, Alba, 2013, How does harvesting affect the source and quantity of instream sediment and how does that affect instream organisms?: Oregon State University Trask Watershed Study, accessed February 2015, at http://www.forestry. oregonstate.edu/sites/www.forestry.oregonstate.edu/files/ Trask_December,\%202013\%20Report_Hatten.pdf.

Helsel, D.R., and Hirsh, R.M., 2002, Statistical methods in water resources: U.S. Geological Survey Techniques and Methods, book 4, chap. A3, 523 p., http://pubs.usgs.gov/ twri/twri4a3/.

Johnson, York, and Drake, Doug, 2011, Water quality status and action plan-North Coast Basin: Oregon Department of Environmental Quality Report 11-WQ-042, 52 p.

Jones, K.L., Keith, M.K, O’Connor, J.E., Mangano, J.F., and Wallick, J.R., 2012, Preliminary assessment of channel stability and bed-material transport in the Tillamook Bay tributaries and Nehalem River basin, northwestern Oregon: U.S. Geological Survey Open-File Report 2012-1187, 120 p., http://pubs.usgs.gov/of/2012/1187/.

Komar, P.D., McManus, James, and Styllas, Michael, 2004, Sediment accumulation in Tillamook Bay, Oregon-Natural processes versus human impacts: Journal of Geology, v. 112, p. 455-469

Mico, C., and Mico, L., 2009, Tillamook Bay watershed sediment and physical habitat assessment: Demeter Design, Prepared for Tillamook Estuaries Partnership, 154 p.
National Weather Service, 2014, Wilson River near Tillamook-Historic crests: Advanced Hydrologic Prediction Service, accessed January 2015, at http://water. weather.gov/ahps2/hydrograph.php?wfo=pqr\&gage=tlmo3 \&view=1,1,1,1,1,1,1,1.

Northwest Hydraulic Consultants, 2011, Southern flow corridor landowner preferred alternative preliminary design report: Northwest Hydraulic Consultants, Prepared for Oregon Solutions Design Team, 17 p., accessed June 2014, at http://www.co.tillamook.or.us/gov/Bocc/Documents/ SouthernFlowCorridorDesignReportFinal.pdf.

Oregon Department of Environmental Quality, 2001, Tillamook Bay watershed total maximum daily load (TMDL):Oregon Department of Environmental Quality, $80 \mathrm{p}$.

Oregon Department of Environmental Quality, 2005a, Fish use designations, north coast basin, Oregon: Oregon Department of Environmental Quality, Figure 230A, accessed December 2014, at http://www.deq.state.or.us/wq/ rules/div041/fufigures/figure230a.pdf.

Oregon Department of Environmental Quality, 2005b, Salmon and steelhead spawning use designations, north coast basin, Oregon: Oregon Department of Environmental Quality, Figure 230B, accessed December 2014, at http://www.deq. state.or.us/wq/rules/div041/fufigures/figure230b.pdf.

Oregon Department of Environmental Quality, 2012, Waterquality assessment-Oregon's 2012 integrated report assessment database and 303(d) list: Oregon Department of Environmental Quality, accessed July 2014, at http://www. deq.state.or.us/wq/assessment/rpt2012/search.asp.

Oregon Department of Environmental Quality, 2014, Oregon Administrative Rules (OAR) — Water-quality standardsBeneficial uses, policies, and criteria for Oregon: Oregon Department of Environmental Quality, OAR 340-041, accessed December 2014, at http://arcweb.sos.state.or.us/ pages/rules/oars_300/oar_340/340_041.html.

Rantz, S.E., and others, 1982, Measurements and computation of streamflow: U.S. Geological Survey Water Supply Paper 2175, v. 2, p. 285-631, http://pubs.usgs.gov/wsp/wsp2175/.

Rasmussen, P.P., and Gray, J.R., 2014, Computing timeseries suspended-sediment concentrations and loads from in-stream turbidity-sensor and streamflow data: U.S. Geological Survey Surface Water Information, accessed March 2015, at http://water.usgs.gov/osw/suspended_ sediment/time_series.html. 
Rasmussen, P.P., Gray, J.R., Glysson, G.D., and Ziegler, A.C., 2009, Guidelines and procedures for computing time-series suspended-sediment concentrations and loads from in-stream turbidity-sensor and streamflow data: U.S. Geological Survey Techniques and Methods, book 3, chap. C4, 53 p., http://pubs.usgs.gov/tm/tm3c4/.

Reiter, Maryanne, Johnson, S.L., and James, Peter, 2013, Stream temperature pattern and processes in the Trask watershed study-Pre-harvest: Weyerhaeuser and U.S. Forest Service, Watersheds Research Cooperative Conference, accessed March 2015, at http://watershedsresearch.org/ assets/reports/WRC_Reiter,\%20Johnson_Trask\%20 Temps\%20varibility_2013_S1.pdf.

Risley, John, Stonewall, Adam, and Haluska, Tana, 2008, Estimating flow-duration and low-flow frequency statistics for unregulated streams in Oregon: U.S. Geological Survey Scientific Investigations Report 2008-5126, 22 p., http:// pubs.usgs.gov/sir/2008/5126/.

Sauer, V.B., and Turnipseed, D.P., 2010, State measurement at gaging stations: U.S. Geological Survey Techniques and Methods, book 3, chap A7, 45 p., http://pubs.usgs.gov/tm/ tm3-a7/.

Snyder, K.U., Sullivan, T.J., Moore, D.L., Raymond, R.B., and Gilbert, E.H., 2003, Trask River watershed analysis: E\&S Environmental Chemistry, Inc., prepared for Oregon Department of Forestry and U.S. Bureau of Land Management, accessed December 2014, at http://www. oregon.gov/odf/pages/state_forests/trask_river_watershed_ analysis.aspx.

Sullivan, T.J., Bishoff, J.M., Snyder, K.U., Raymond, R.B., White, Shawn, and Binder, S.K., 2001, Wilson River watershed assessment: E\&S Environmental Chemistry, Inc., 178 p., plus appendices.

Tillamook Estuaries Partnership, 1999, Restoring the balance-Comprehensive conservation and management plan for Tillamook Bay, Oregon: Tillamook County Performance Partnership, accessed September 2014, at http://www.monae.org/documents/Tillamook\%20Bay\%20 monitoring\%20plan.pdf.
Tillamook Estuaries Partnership, 2010, Tillamook Bay watershed health report 2010: U.S. Environmental Protection Agency, 25 p., accessed April 2015, at http:// water.epa.gov/type/oceb/nep/upload/sob_final_rpt_2010. pdf.

Turnipseed, D.P., and Sauer, V.B., 2010, Discharge measurements at gaging stations: U.S. Geological Survey Techniques and Methods, book 3, chap A8, 87 p., http:// pubs.usgs.goc/tm/tm3-a8/.

U.S. Geological Survey, 2006, Collection of water samples (ver. 2.0): U.S. Geological Survey Techniques of WaterResources Investigations, book 9, chap. A4, September 2006, accessed December 2014, at http://pubs.water.usgs. gov/twri9A4/.

U.S. Geological Survey, 2015a, National Water Information System Web Interface-Wilson River near Tillamook, Oregon: accessed June 10, 2015, at http://waterdata.usgs. gov/or/nwis/inventory/?site_no=14301500\&agency_ $\mathrm{cd}=\mathrm{USGS}$.

U.S. Geological Survey, 2015b, National Water Information System Web Interface-Trask River above Cedar Creek, near Tillamook, Oregon: accessed June 10, 2015, at http://waterdata.usgs.gov/or/nwis/inventory/?site_ no $=14302480 \&$ agency_cd=USGS.

Wagner, R.J., Boulger, R.W., Jr., Oblinger, C.J., and Smith, B.A., 2006, Guidelines and standard procedures for continuous water-quality monitors-station operation, record computation, and data reporting: U.S. Geological Survey Techniques and Methods 1-D3, $51 \mathrm{p}$.

YSI, 2013, Anti-fouling C-Spray protective probe solution: Website accessed February 2015, at http://www.ysi.com/ accessoriesdetail.php?Anti-fouling-C-Spray-ProtectiveProbe-Solution-129. 


\section{Appendix A. Wilson River Suspended-Sediment Concentration Record}

\section{Model Calibration Dataset}

Suspended-sediment concentration (SSC) samples were collected using U.S. Geological Survey (USGS) protocols and were stored online in the National Water Information System database. Samples were collected over nearly the entire range of turbidity and streamflow conditions for the 3 years analyzed (water years 2012-14). The ordinary least-squares regression model was based on 25 equal-width-increment (EWI) sampling events where concurrent instream turbidity and streamflow data were available. The model inputs were either the event averages of multiple sample sets (EWI-A and EWI-B) or from single samples (EWI, table A1).

\section{Methods for Assigning Turbidity and Streamflow}

To assign turbidity values to discrete SSC samples, continuous (15-minute) instream turbidity data were averaged over the period of EWI sample collection. Turbidity values were averaged starting with the data value immediately before the start of the EWI collection period and ending with the data value immediately after the end of the EWI collection period. Streamflow values were timeweighted between the two 15-minute data values before and after the mean time of the SSC sample. For mean samples times collected on a 15-minute mark, single unit values of streamflow were used (table A1).

\section{Model Development}

All regression analyses were done with the “Turbidity Sediment Spreadsheet” using the methods described in Rasmussen and others (2009). Turbidity and streamflow were evaluated separately and together, $\log _{10}$-transformed and untransformed, as possible surrogates. Turbidity and streamflow were too highly correlated to one another (high variance inflation factor; VIF $=13$ ) to use both parameters. The $\log _{10}$-transformed turbidity model was chosen on the basis of residual plots, adjusted coefficient of determination, model standard percent error, probability plot correlation coefficient, and prediction error sum of squares statistics. Residual plots for evaluating variance, normality, homoscedasticity, and curvature are provided (fig. A1). For the $\log _{10}$-transformed model, computed SSC values were multiplied by a retransformation bias correction factor.

\section{Model Information}

The model used for the Wilson River is represented as:

$$
\log _{10} \mathrm{SSC}=0.361+1.05 \log _{10} \mathrm{~TB}
$$

-See equation 1 and table 3

-Number of measurements $=25$

-Standard error $(\mathrm{SE})=0.20$

-Upper model standard percent error $(\mathrm{MSPE})=+57.2$ percent

-Lower model standard percent error (MSPE) $=-36.4$ percent

-Adjusted coefficient of determination $\left(\operatorname{Adj} \mathrm{R}^{2}\right)=0.95$

-Probability plot correlation coefficient $(\mathrm{PPCC})=0.97$

-Prediction error sum-of-squares $($ PRESS) $=1.17$

-Duan bias correction factor $(\mathrm{BCF})=1.11$

\section{Suspended-Sediment Concentration Record}

SSC time-series data were computed from the 15-minute turbidity data. During short periods of missing or deleted turbidity data, the SSC unit values were estimated by interpolating between the computed SSC values. The daily mean SSC estimated dates were:

\begin{tabular}{llll}
\hline Nov. 22, 2011 & Jan. 3-5, 2012 & Mar. 16, 2013 & Jan. 22, 2014 \\
Nov. 26-28, 2011 & Mar. 12-13, 2012 & June 5-6, 2013 & Mar. 14, 2014 \\
Dec. 24-25, 2011 & Mar. 21-23, 2012 & June 20-25, 2013 & May 23-29, 2014 \\
& Apr. 25, 2012 & July 14, 2013 & June 12-July 10, 2014 \\
& May 16-17, 2012 & & July 17, 2014 \\
& June 26, 2012 & & Aug. 5-11, 2014 \\
& July 2-3, 2012 & Aug. 24-26, 2014 \\
& July 5, 2012 & \\
& July 7, 2012 & \\
& July 17-24, 2012 & \\
& Aug. 19, 2012 & \\
& Nov. 3-5, 2012 & \\
& Nov. 19, 2012 & \\
& Mar. 2-3, 2012 & \\
\hline
\end{tabular}

Summary statistics for the regression model dataset and the continuous turbidity and SSC records are provided in table A2. The continuous SSC data and 90-percent prediction intervals are shown in figures A2-A4. 
Table A1. Suspended-sediment sample and model calibration data for the Wilson River, northwestern Oregon.

[Sample type/set: EWI is a single sample; EWI-A/B/C are consecutive samples and are averaged into an event average. Abbreviations: EWI, equal-widthincrement; FNU, Formazin Nephelometric Unit; $\mathrm{ft}^{3} / \mathrm{s}$, cubic feet per second; $\mathrm{mg} / \mathrm{L}$, millligrams per liter; $\mu \mathrm{m}$, micrometers]

\begin{tabular}{|c|c|c|c|c|c|c|c|}
\hline \multicolumn{2}{|c|}{$\begin{array}{c}\text { Date and time } \\
\text { (local Pacific time) }\end{array}$} & \multirow{2}{*}{\begin{tabular}{|l}
$\begin{array}{r}\text { Sample } \\
\text { type/set }\end{array}$ \\
EWI-A
\end{tabular}} & \multirow{2}{*}{$\begin{array}{c}\begin{array}{c}\text { Turbidity } \\
\text { (FNU) }\end{array} \\
2.1\end{array}$} & \multirow{2}{*}{$\begin{array}{c}\begin{array}{c}\text { Streamflow } \\
\left(\mathbf{f t}^{3} / \mathbf{s}\right)\end{array} \\
556\end{array}$} & \multirow{2}{*}{$\begin{array}{c}\begin{array}{c}\text { Suspended- } \\
\text { sediment } \\
\text { concentration } \\
\text { (mg/L) }\end{array} \\
2\end{array}$} & \multirow{2}{*}{$\begin{array}{c}\text { Sediment } \\
\text { finer than } \\
63 \mu \mathrm{m} \\
\text { (percent) } \\
-\end{array}$} & \multirow{2}{*}{$\begin{array}{r}\text { Record No. } \\
1200045\end{array}$} \\
\hline 11-14-2011 & $10: 55$ & & & & & & \\
\hline & 11:02 & EWI event average & 2.1 & 556 & 2 & - & 1201907 \\
\hline & $11: 10$ & EWI-B & 2.1 & 556 & 2 & - & 1200046 \\
\hline $11-22-2011$ & $15: 48$ & EWI & 380 & 16,300 & 966 & 73 & 1200030 \\
\hline $11-29-2011$ & $13: 10$ & EWI & 5.4 & 1,860 & 8 & 79 & 1200065 \\
\hline 12-07-2011 & $16: 20$ & EWI & 1.4 & 715 & 2 & - & 1200090 \\
\hline \multirow[t]{4}{*}{ 01-19-2012 } & $13: 35$ & EWI-A & 68 & 9,070 & 618 & 20 & 1200136 \\
\hline & $14: 05$ & EWI-B & 71 & 9,360 & 446 & 30 & 1200137 \\
\hline & $14: 08$ & EWI event average & 71 & 9,440 & 527 & 27 & 1201908 \\
\hline & $14: 45$ & EWI-C & 75 & 9,900 & 516 & 32 & 1200140 \\
\hline 01-24-2012 & $16: 43$ & EWI & 26 & 5,200 & 115 & 38 & 1200149 \\
\hline \multirow[t]{3}{*}{ 01-25-2012 } & $11: 00$ & EWI-A & 76 & 9,630 & 245 & 52 & 1200152 \\
\hline & 11:09 & EWI event average & 74 & 9,560 & 260 & 48 & 1200153 \\
\hline & $11: 18$ & EWI-B & 72 & 9,500 & 276 & 45 & 1200153 \\
\hline 02-06-2012 & $16: 05$ & EWI & 0.7 & 1,140 & 4 & 50 & 1200205 \\
\hline \multirow[t]{7}{*}{ 03-15-2012 } & $12: 50$ & EWI-A & 350 & 18,500 & 1,530 & 56 & 1201909 \\
\hline & 13:05 & EWI event average & 370 & 18,600 & 1,630 & 55 & 1200225 \\
\hline & $13: 20$ & EWI-B & 390 & 18,700 & 1,730 & 54 & 1201910 \\
\hline & $13: 47$ & EWI-A & 390 & 18,800 & 1,690 & 54 & 1201911 \\
\hline & $14: 01$ & EWI event average & 380 & 18,800 & 1,680 & 54 & 1200231 \\
\hline & $14: 14$ & EWI-B & 380 & 18,700 & 1,660 & 54 & 1201912 \\
\hline & $18: 14$ & EWI & 280 & 17,500 & 1,090 & 51 & 1200235 \\
\hline 03-16-2012 & $10: 58$ & EWI & 130 & 9,980 & 359 & 59 & 1200240 \\
\hline \multirow[t]{3}{*}{ 05-23-2012 } & $15: 50$ & EWI-A & 1 & 1,170 & 4 & - & 1200333 \\
\hline & $16: 06$ & EWI event average & 1 & 1,160 & 4 & - & 1201913 \\
\hline & $16: 22$ & EWI-B & 1 & 1,160 & 3 & - & 1200334 \\
\hline \multirow[t]{4}{*}{ 10-29-2012 } & $11: 55$ & EWI-A & 69 & 7,740 & 216 & 48 & 1300124 \\
\hline & $12: 20$ & EWI event average & 66 & 7,520 & 220 & 46 & 1300127 \\
\hline & $12: 35$ & EWI-B & 64 & 7,390 & 225 & 43 & 1300125 \\
\hline & $12: 55$ & EWI-C & 63 & 7,200 & 223 & 44 & 1300126 \\
\hline $10-30-2012$ & $12: 35$ & EWI-A & 17 & 3,880 & 46 & 39 & 1301527 \\
\hline
\end{tabular}


Table A1. Suspended-sediment sample and model calibration data for the Wilson River, northwestern Oregon.-Continued

\begin{tabular}{|c|c|c|c|c|c|c|c|}
\hline \multicolumn{2}{|c|}{$\begin{array}{l}\text { Date and time } \\
\text { (local Pacific time) }\end{array}$} & \multirow[t]{2}{*}{$\begin{array}{l}\text { Sample } \\
\text { type/set }\end{array}$} & \multirow{2}{*}{$\begin{array}{c}\begin{array}{c}\text { Turbidity } \\
\text { (FNU) }\end{array} \\
17\end{array}$} & \multirow{2}{*}{$\begin{array}{c}\begin{array}{c}\text { Streamflow } \\
\left(\mathbf{f t} \mathbf{t}^{3} / \mathbf{s}\right)\end{array} \\
3,960\end{array}$} & \multirow{2}{*}{$\begin{array}{c}\begin{array}{c}\text { Suspended- } \\
\text { sediment }\end{array} \\
\text { concentration } \\
\text { (mg/L) }\end{array}$} & \multirow{2}{*}{$\begin{array}{c}\text { Sediment } \\
\text { finer than } \\
\mathbf{6 3} \boldsymbol{\mu m} \\
\text { (percent) }\end{array}$} & \multirow{2}{*}{$\begin{array}{c}\text { Record No. } \\
1300134\end{array}$} \\
\hline \multirow{4}{*}{ 10-31-2012 } & $12: 55$ & & & & & & \\
\hline & 13:15 & EWI-B & 17 & 4,040 & 42 & 44 & 1301528 \\
\hline & 11:51 & EWI-A & 27 & 5,400 & 60 & 52 & 1300141 \\
\hline & $12: 08$ & EWI event average & 27 & 5,400 & 60 & 52 & 1301529 \\
\hline & $12: 25$ & EWI-B & 27 & 5,400 & 60 & - & 1300143 \\
\hline \multirow[t]{6}{*}{$11-19-2012$} & 12:59 & EWI-A & 380 & 18,400 & 929 & 65 & 1300063 \\
\hline & 13:26 & EWI Event Average & 375 & 18,800 & 950 & 70 & 1301530 \\
\hline & 13:53 & EWI-B & 370 & 19,200 & 971 & 74 & 1301531 \\
\hline & $14: 35$ & EWI-A & 410 & 19,700 & 1,030 & 77 & 1300072 \\
\hline & $14: 42$ & EWI event average & 410 & 19,800 & 1,060 & 76 & 1301532 \\
\hline & 14:50 & EWI-B & 410 & 19,900 & 1,100 & 74 & 1300074 \\
\hline \multirow[t]{3}{*}{ 11-20-2012 } & $13: 24$ & EWI-A & 150 & 8,920 & 295 & 76 & 1300085 \\
\hline & 13:29 & EWI event average & 150 & 8,900 & 295 & 76 & 1301533 \\
\hline & 13:34 & EWI-B & 150 & 8,890 & 295 & 75 & 1300087 \\
\hline \multirow[t]{3}{*}{ 11-21-2012 } & 12:14 & EWI-A & 50 & 5,470 & 106 & 66 & 1300101 \\
\hline & $12: 22$ & EWI event average & 50 & 5,450 & 110 & 62 & 1301534 \\
\hline & $12: 31$ & EWI-B & 50 & 5,430 & 114 & 58 & 1300102 \\
\hline \multirow[t]{3}{*}{ 12-05-2012 } & 10:35 & EWI-A & 51 & 6,600 & 110 & 58 & 1300184 \\
\hline & $10: 46$ & EWI event average & 50 & 6,580 & 110 & 56 & 1301535 \\
\hline & 10:55 & EWI-B & 48 & 6,570 & 110 & 55 & 1300186 \\
\hline \multirow[t]{3}{*}{ 09-29-2013 } & $10: 24$ & EWI-A & 53 & 6,550 & 127 & 59 & 1301536 \\
\hline & 10:38 & EWI event average & 54 & 6,620 & 126 & 57 & 1300854 \\
\hline & 10:59 & EWI-B & 54 & 6,690 & 124 & 55 & 1301537 \\
\hline \multirow[t]{3}{*}{ 11-19-2013 } & 09:52 & EWI-A & 80 & 6,840 & 180 & 60 & 1400037 \\
\hline & 10:06 & EWI event average & 80 & 6,830 & 185 & 58 & 1400040 \\
\hline & $10: 20$ & EWI-B & 79 & 6,820 & 190 & 55 & 1400042 \\
\hline \multirow[t]{3}{*}{$12-02-2013$} & 14:05 & EWI-A & 72 & 7,130 & 156 & 62 & 1400077 \\
\hline & 14:19 & EWI event average & 71 & 7,040 & 150 & 66 & 1400775 \\
\hline & 14:34 & EWI-B & 70 & 6,950 & 143 & 69 & 1400080 \\
\hline \multirow{3}{*}{ 02-12-2014 } & 11:03 & EWI-A & 130 & 10,100 & 333 & 66 & 1400254 \\
\hline & 11:19 & EWI event average & 130 & 9,790 & 322 & 65 & 1400776 \\
\hline & 11:35 & EWI-B & 130 & 9,480 & 312 & 64 & 1400255 \\
\hline
\end{tabular}


Table A2. Summary statistics for model calibration and continuous turbidity and suspended-sediment concentration for the Wilson River, northwestern Oregon.

[C ontinuous data: SSC, suspended-sediment concentration; WY, water year. A bbreviations: FNU, Formazin Nephelometric Unit; mg/L, millligrams per liter]

\begin{tabular}{|c|c|c|c|c|c|c|c|c|}
\hline \multirow{2}{*}{$\begin{array}{c}\text { Summary } \\
\text { statistic }\end{array}$} & \multirow{2}{*}{\multicolumn{2}{|c|}{$\begin{array}{c}\text { Model calibration data } \\
\text { (number of sampling } \\
\text { events }=25 \text { ) }\end{array}$}} & \multicolumn{6}{|c|}{ Continuous data (15-minute interval) } \\
\hline & & & \multicolumn{2}{|c|}{ WY2012 } & \multicolumn{2}{|c|}{ WY2013 } & \multicolumn{2}{|c|}{ WY2014 } \\
\hline Minimum & 1 & 2 & 0 & 0 & 0.2 & 0.5 & 0.1 & 0.2 \\
\hline Maximum & 410 & 1,680 & 600 & 2,110 & 540 & 1,890 & 250 & 843 \\
\hline Mean & 71 & 185 & 8.2 & 25.7 & 5.6 & 16.9 & 4.6 & 13.7 \\
\hline
\end{tabular}
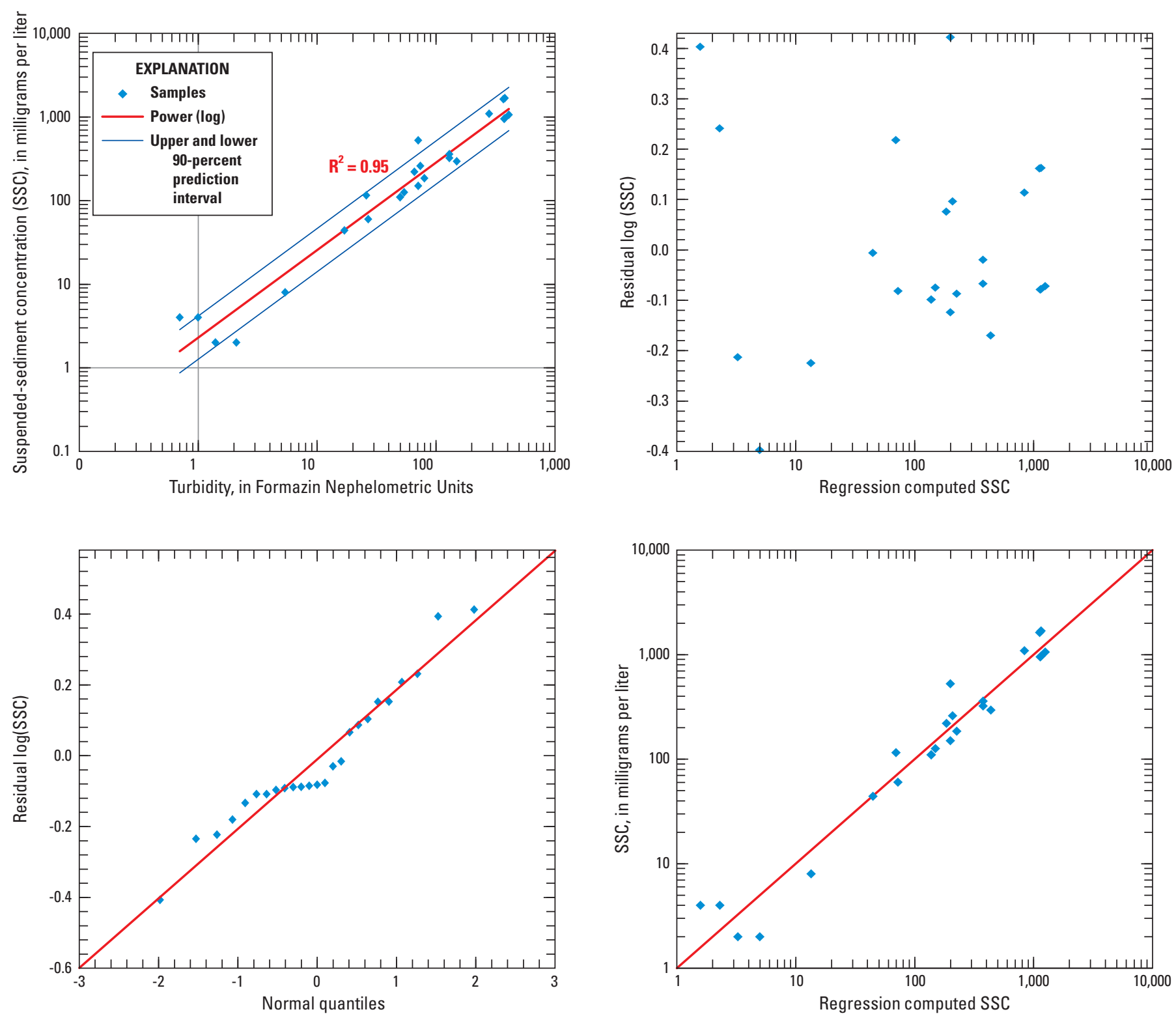

Figure A1. Ordinary least-squares regression model plots for the Wilson River, northwestern Oregon. 

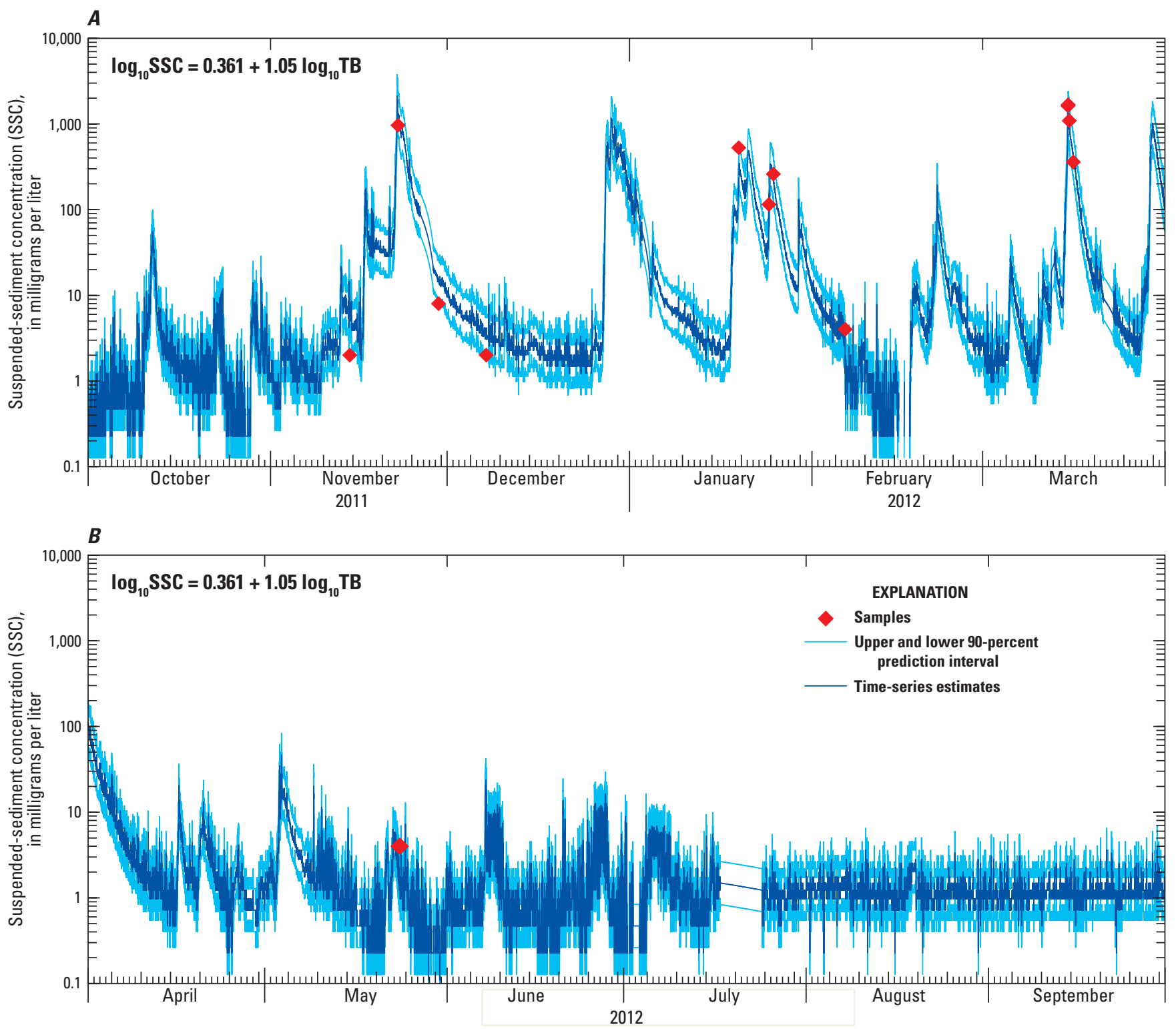

Figure A2. Suspended-sediment concentration (SSC) data, 90-percent prediction intervals, and sample data at the Wilson River, northwestern Oregon, October 2011-March 2012 and April-September 2012. 

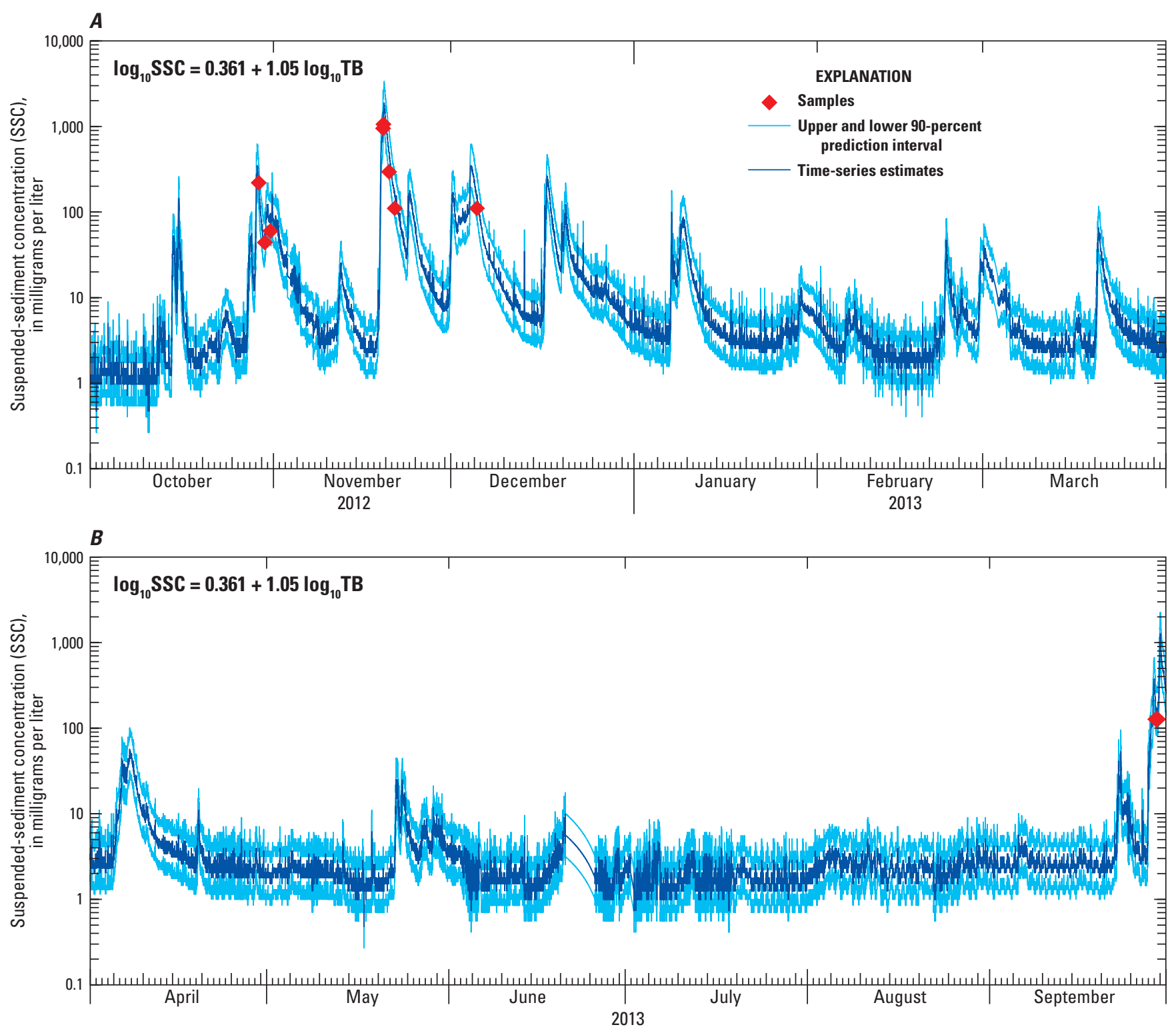

Figure A3. Suspended-sediment concentration (SSC) data, 90-percent prediction intervals, and sample data at the Wilson River, northwestern Oregon, October 2012-March 2013 and April-September 2013. 

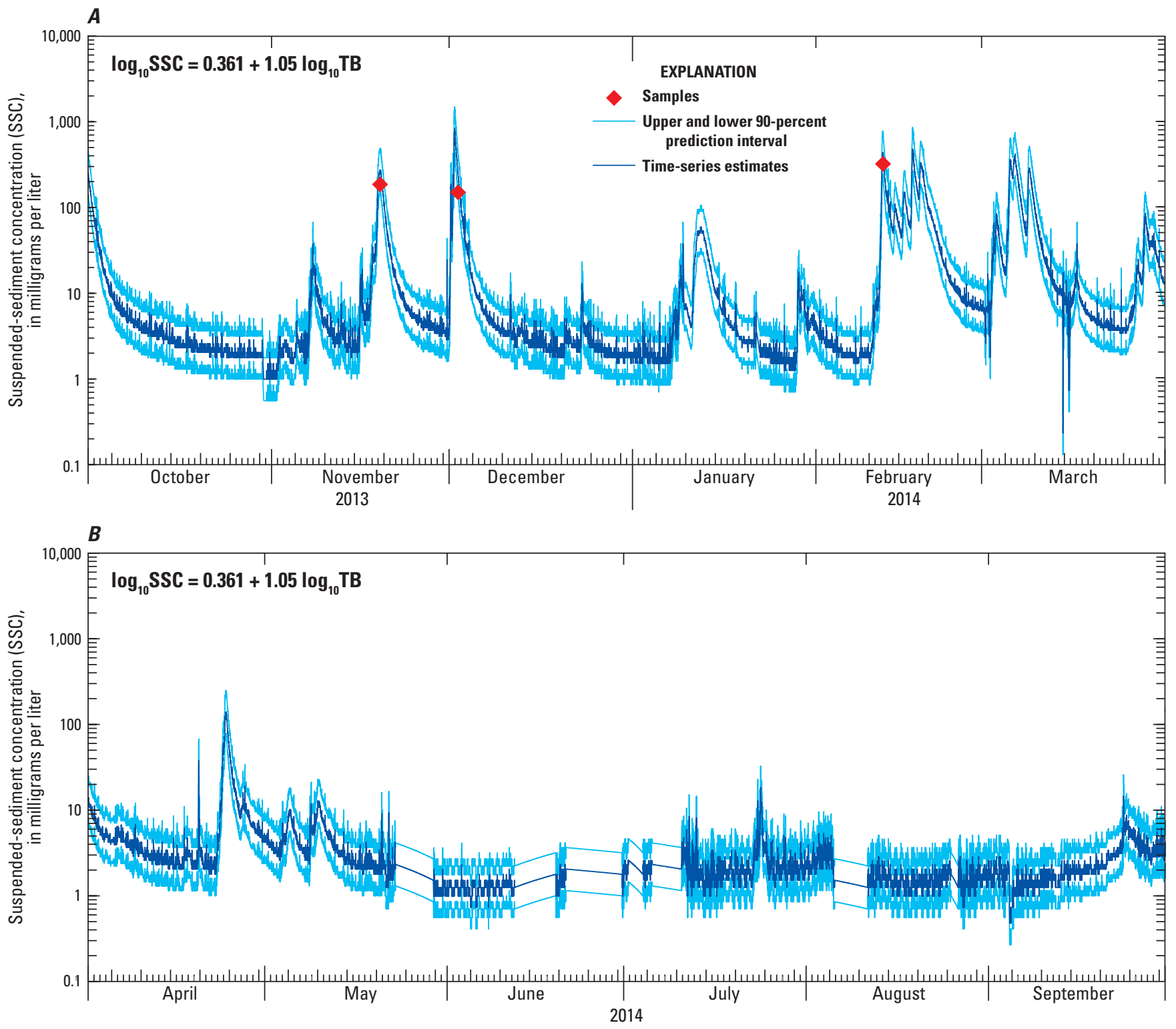

Figure A4. Suspended-sediment concentration (SSC) data, 90-percent prediction intervals, and sample data at the Wilson River, northwestern Oregon, October 2012-March 2013 and April-September 2013. 
22 Water-Quality Conditions and Suspended-Sediment Transport, Wilson and Trask Rivers, Oregon, Water Years 2012-14

This page intentionally left blank. 


\section{Appendix B. Trask River Suspended-Sediment Concentration Record}

\section{Model Calibration Dataset}

All suspended-sediment concentration (SSC) samples were collected using USGS protocols and are stored in the U.S. Geological Survey National Water Information System database. Samples were collected over nearly the entire range of turbidity and streamflow conditions for the 3 years analyzed (water years 2012-14). The ordinary least-squares regression model was based on 23 equal-width-increment (EWI) sampling events where concurrent instream turbidity and streamflow data were available. The model inputs were either the event averages of multiple sample sets (EWI-A and EWI-B) or from single samples (EWI, table B1).

\section{Time-of-Travel Correction}

The location of the water-quality monitor and streamgage was about 4 river miles $(21,120 \mathrm{ft})$ upstream of the sampling location on the Long Prairie Road Bridge. To account for this difference, all suspended-sediment sample times were adjusted for time-of-travel. The computation used the mean velocity of all streamflow measurements from water years 2008-2014 and two high-streamflow measurements from water years 1998 and 1999 (47 measurements total). The time-of-travel during the streamflow measurements was computed using:

$$
t=\frac{\frac{d}{1.3 * v}}{c}
$$

where

$$
\begin{aligned}
t & \text { is time-of-travel (hr), } \\
d & \text { is the distance (ft), } \\
v & \text { is the mean velocity (ft/s), and } \\
c & \text { is a conversion constant to convert seconds to } \\
& \text { hours (equal to 3,600 } \mathrm{s} / \mathrm{hr} \text { ). }
\end{aligned}
$$

The discrete measured streamflow and associated timeof-travel values were plotted and a power function trend line was fit to the data. The resulting equation was used to determine the time-of-travel correction for each suspendedsediment sample based on the streamflow at the actual mean sample time:

$$
t=14 * Q^{-0.294}
$$

where

$$
\begin{aligned}
t & \text { is time-of-travel (hr), and } \\
Q & \text { is streamflow }\left(\mathrm{ft}^{3} / \mathrm{s}\right) .
\end{aligned}
$$

The time-of-travel adjustment was subtracted from the actual mean sample times for each sample for assigning streamflow values. Adjusted begin and end sample times also were used for computing average turbidity values for the samples (table B1).

\section{Methods for Assigning Turbidity and Streamflow}

To assign turbidity values to discrete SSC samples, continuous (30- or 15-minute) instream turbidity data were averaged over the period of EWI sample collection. Turbidity values were averaged starting with the data value immediately before the start time (adjusted for time-of-travel) of the EWI and ending with the data value immediately after the end time (adjusted for time-of-travel) of the EWI. Streamflow values were time-weighted between the two 30- or 15-minute data values before and after the mean time (adjusted for time-oftravel) of the SSC sample. For mean samples times on a 30- or 15-minute mark, single unit values of streamflow were used (table B2).

\section{Model Development}

Regression analyses were done with the "Turbidity Sediment Spreadsheet" using the methods described in the Rasmussen and others (2009). Turbidity and streamflow were evaluated separately and together, $\log _{10}$-transformed and untransformed, as possible surrogates. The $\log _{10}$-transformed turbidity model was chosen on the basis of residual plots, adjusted coefficient of determination, model standard percent error, probability plot correlation coefficient, and prediction error sum of squares statistics. Residual plots for evaluating variance, normality, homoscedasticity, and curvature are provided in figure B1. For the $\log _{10}$-transformed model, computed SSC values were multiplied by a retransformation bias correction factor. 


\section{Model Information}

The model used for the Trask River site is represented as:

$$
\log _{10} \mathrm{SSC}=0.331+1.06 \log _{10} \mathrm{~TB}
$$

-See equation 1 and table 3

-Number of measurements $=23$

-Standard error $(\mathrm{SE})=0.15$

-Upper model standard percent error $(\mathrm{MSPE})=+42.6$ percent

-Lower model standard percent error $(\mathrm{MSPE})=-29.9$ percent

-Adjusted coefficient of determination $\left(\right.$ Adj $\left.\mathrm{R}^{2}\right)=0.96$

-Probability plot correlation coefficient $(\mathrm{PPCC})=0.94$

-Prediction error sum-of-squares $($ PRESS $)=0.60$

-Duan bias correction factor $(\mathrm{BCF})=1.06$

\section{Suspended-Sediment Content Record}

SSC time-series data were computed from the 15-minute turbidity data. During short periods of missing or deleted turbidity data, the SSC unit values were estimated by interpolating between the computed SSC values.
The daily mean SSC estimated dates were:

\begin{tabular}{llll}
\hline Nov. 17-28, 2011 & May 11-16, 2012 & Apr. 28-29, 2013 & Jan. 13-14, 2014 \\
Dec. 4-7, 2011 & May 24-26, 2012 & May 15, 2013 & Feb. 6-7, 2014 \\
& July 3, 2012 & May 20, 2013 & Feb. 12-15, 2014 \\
& July 14-23, 2012 & June 5-7, 2013 & Feb. 17-19, 2014 \\
& Oct. 24, 2012 & June 23-27, 2013 & Feb. 22-25, 2014 \\
& Oct. 29, 2012 & Oct. 4, 2013 & Mar. 14-16, 2014 \\
& Nov. 1-4, 2012 & Oct. 8, 2013 & May 23-27, 2014 \\
& Nov. 19-21, 2012 & Oct. 24-30, 2013 & May 30-July 1, 2014 \\
& Nov. 26-29, 2012 & Nov. 19, 2013 & Aug. 3-5, 2014 \\
& & Nov. 22-23, 2013 & \\
& & Dec. 2, 2013 & \\
& & Dec. 6, 2013 & \\
& & Dec. 9, 2013 & \\
& & Dec. 19, 2013 & \\
& &
\end{tabular}

Summary statistics for the regression model dataset and the continuous turbidity and SSC records are provided in table B2. The continuous SSC data and 90-percent prediction intervals are shown in figures B2-B4.

Table B1. Suspended-sediment sample and model calibration data for the Trask River, northwestern Oregon.

[Sample type/set: EWI is a single sample; EWI-A/B/C are consecutive samples and are averaged into an event average. Abbreviations: EWI, equal-widthincrement; FNU, Formazin Nephelometric Unit; $\mathrm{ft}^{3} / \mathrm{s}$, cubic feet per second; $\mathrm{mg} / \mathrm{L}$, millligrams per liter; $\mu \mathrm{m}$, micrometers]

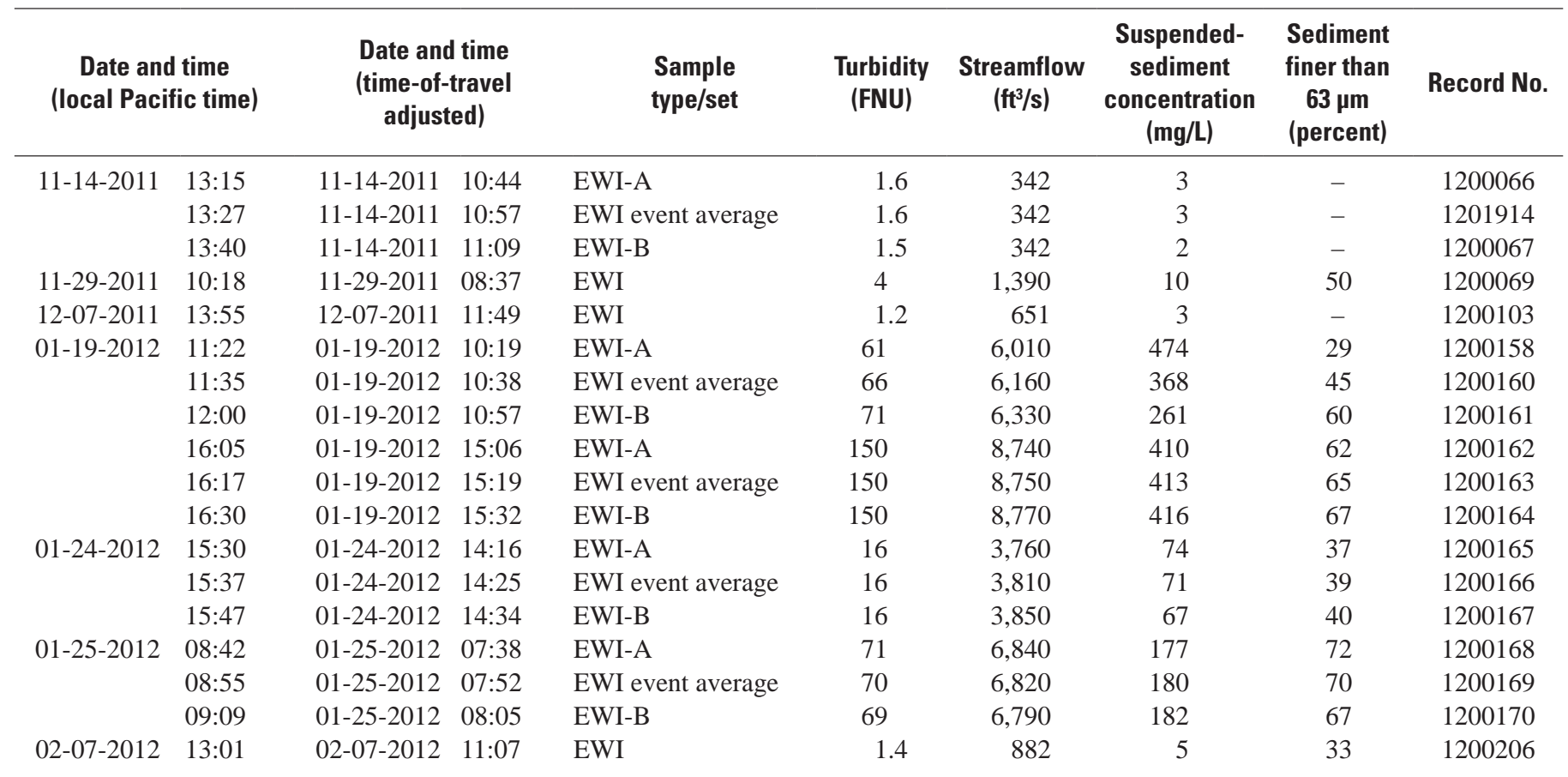


Table B1. Suspended-sediment sample and model calibration data for the Trask River, northwestern Oregon. —Continued

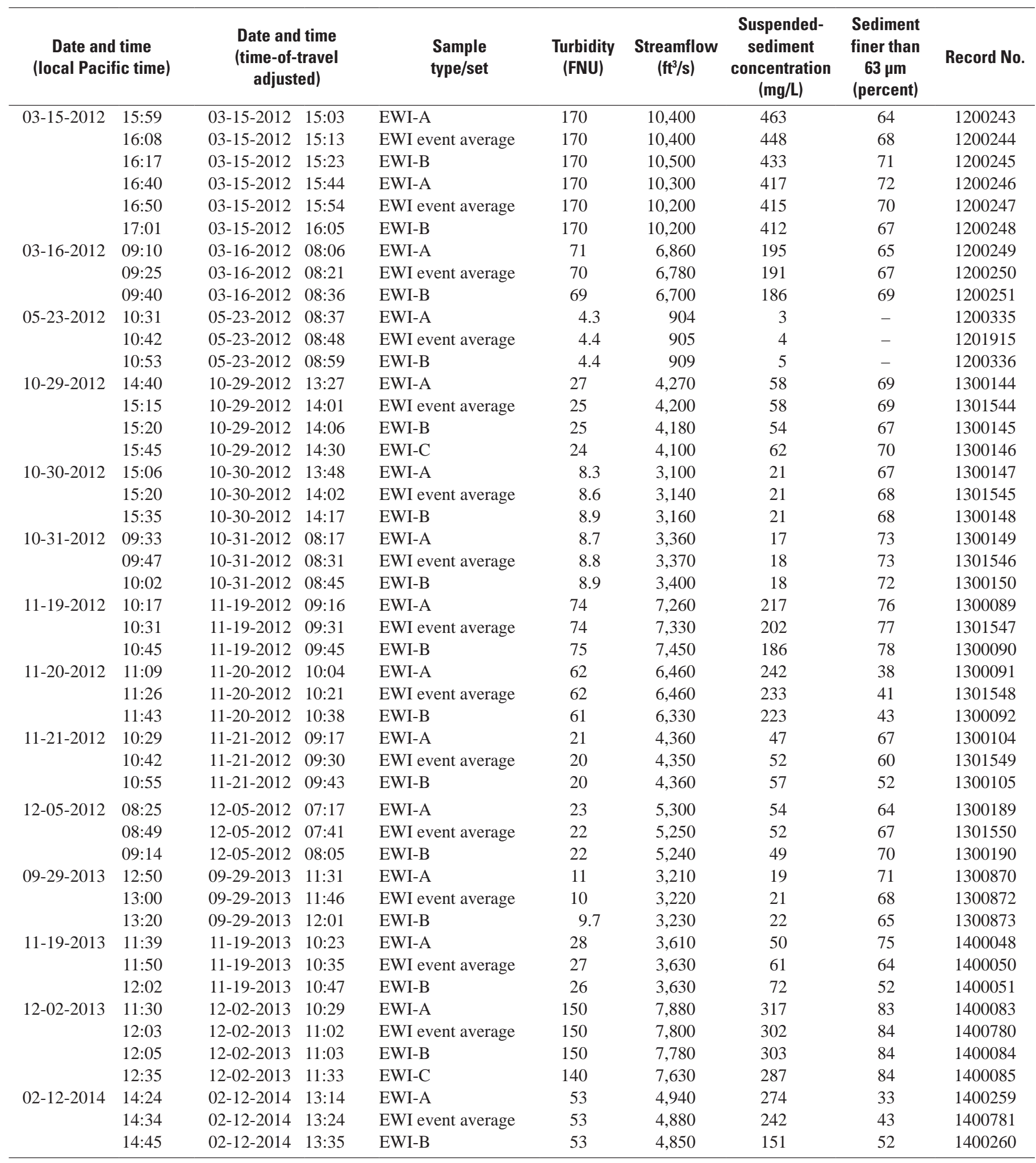


Table B2. Summary statistics for model calibration and continuous turbidity and suspended-sediment concentration for the Trask River, northwestern Oregon.

[C ontinuous data: SSC, suspended-sediment concentration; WY, water year. A bbreviations: FNU, Formazin Nephelometric Unit; mg/L, millligrams per liter]

\begin{tabular}{|c|c|c|c|c|c|c|c|c|}
\hline \multirow{2}{*}{$\begin{array}{c}\text { Summary } \\
\text { statistic }\end{array}$} & \multirow{2}{*}{\multicolumn{2}{|c|}{$\begin{array}{c}\text { Model calibration data } \\
\text { (number of sampling } \\
\text { events = 23) }\end{array}$}} & \multicolumn{6}{|c|}{ Continuous data (15-minute interval) } \\
\hline & & & \multicolumn{2}{|c|}{ WY2012 } & \multicolumn{2}{|c|}{ WY2013 } & \multicolumn{2}{|c|}{ WY2014 } \\
\hline Minimum & 1 & 3 & 0 & 0 & 0 & 0 & 0 & 0 \\
\hline Maximum & 170 & 448 & 180 & 558 & 302 & 966 & 342 & 1,100 \\
\hline Mean & 25 & 61 & 4.7 & 14.1 & 2.8 & 7.4 & 4 & 11 \\
\hline
\end{tabular}
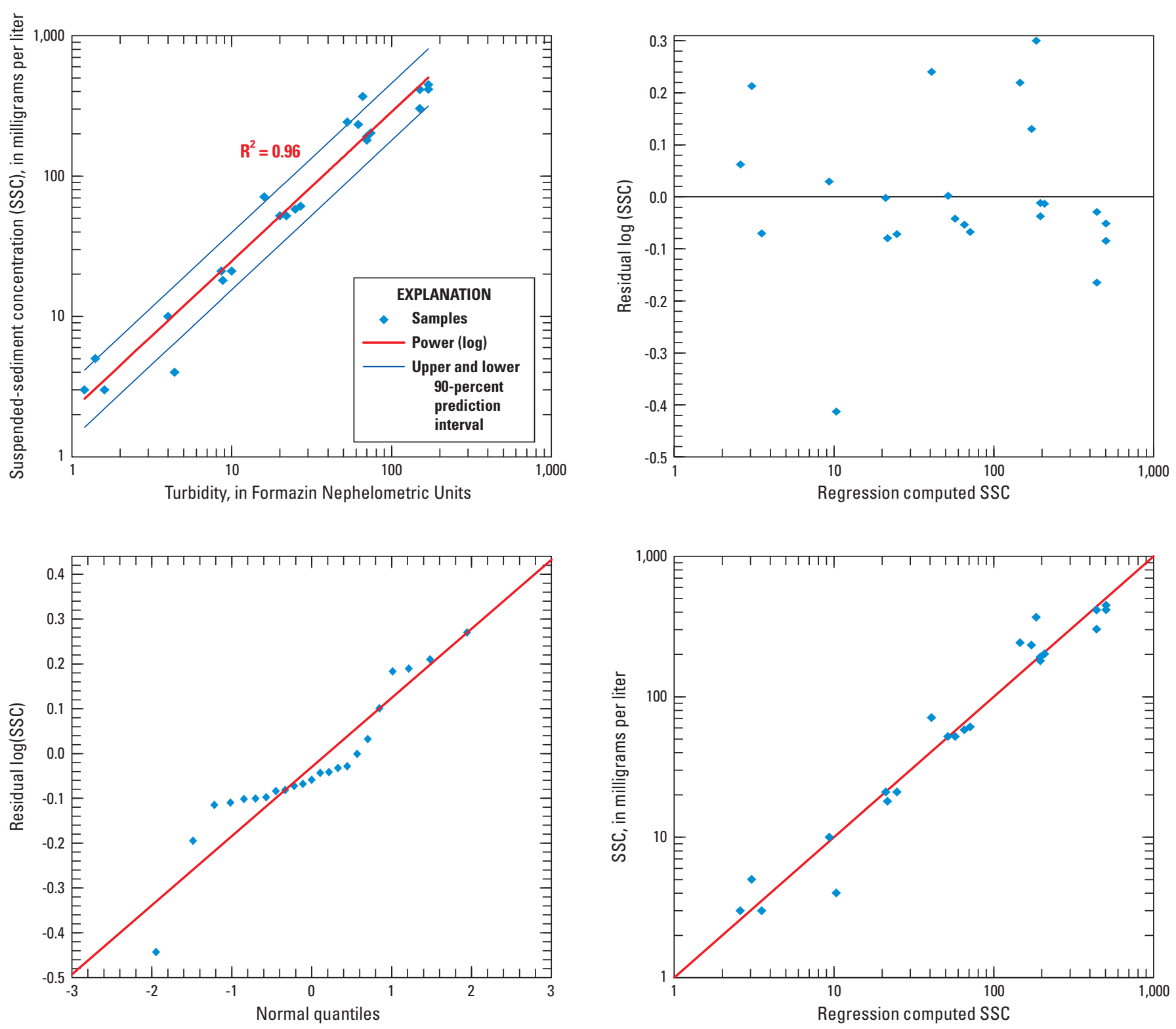

Figure B1. Ordinary least-squares regression model plots for the Trask River, northwestern Oregon. 

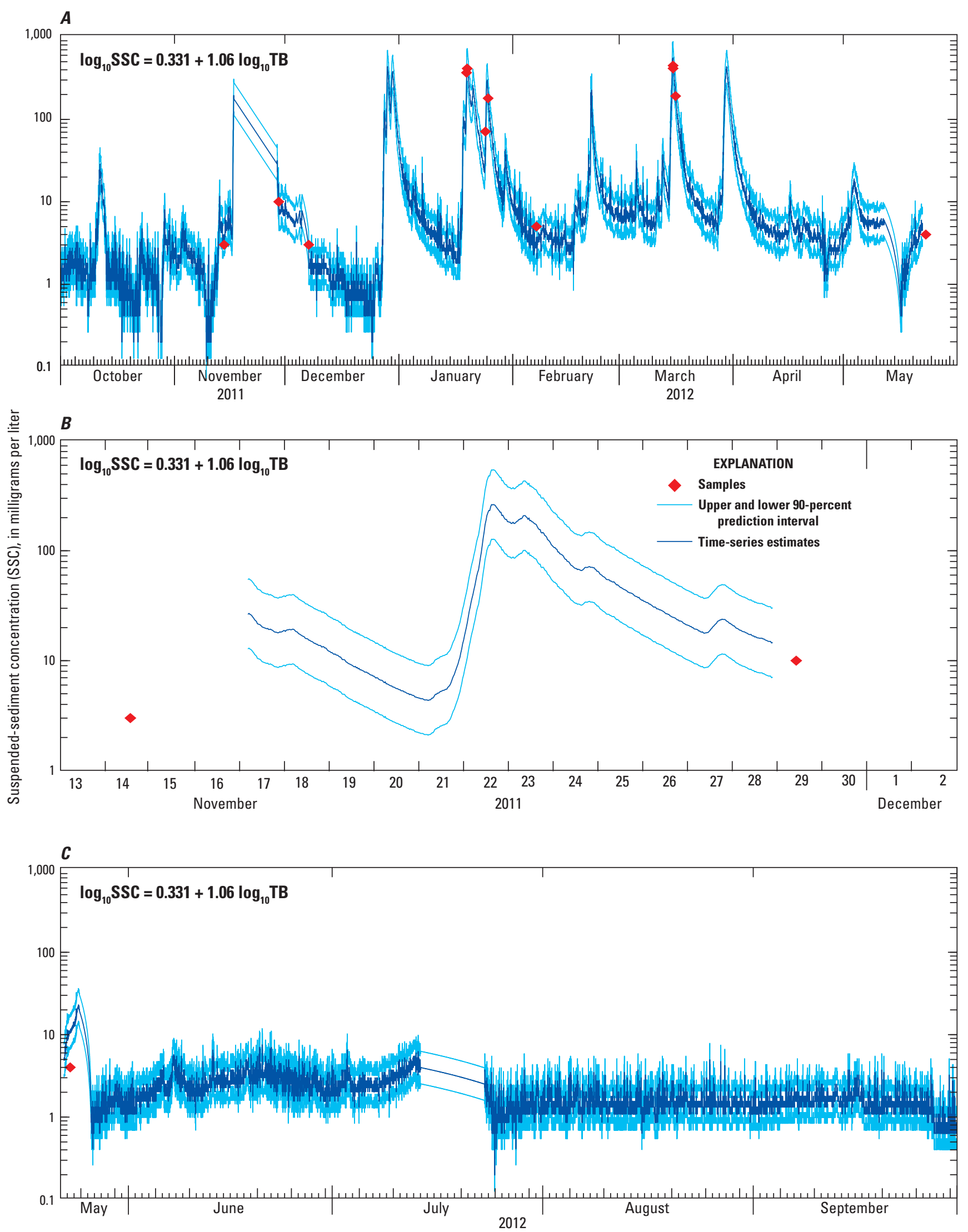

Figure B2. Suspended-sediment concentration (SSC) data, 90-percent prediction intervals, and sample data at the Trask River, northwestern Oregon, October 1, 2011-May 22, 2012, November 18-28, 2011, and May 22-September 30, 2012. 

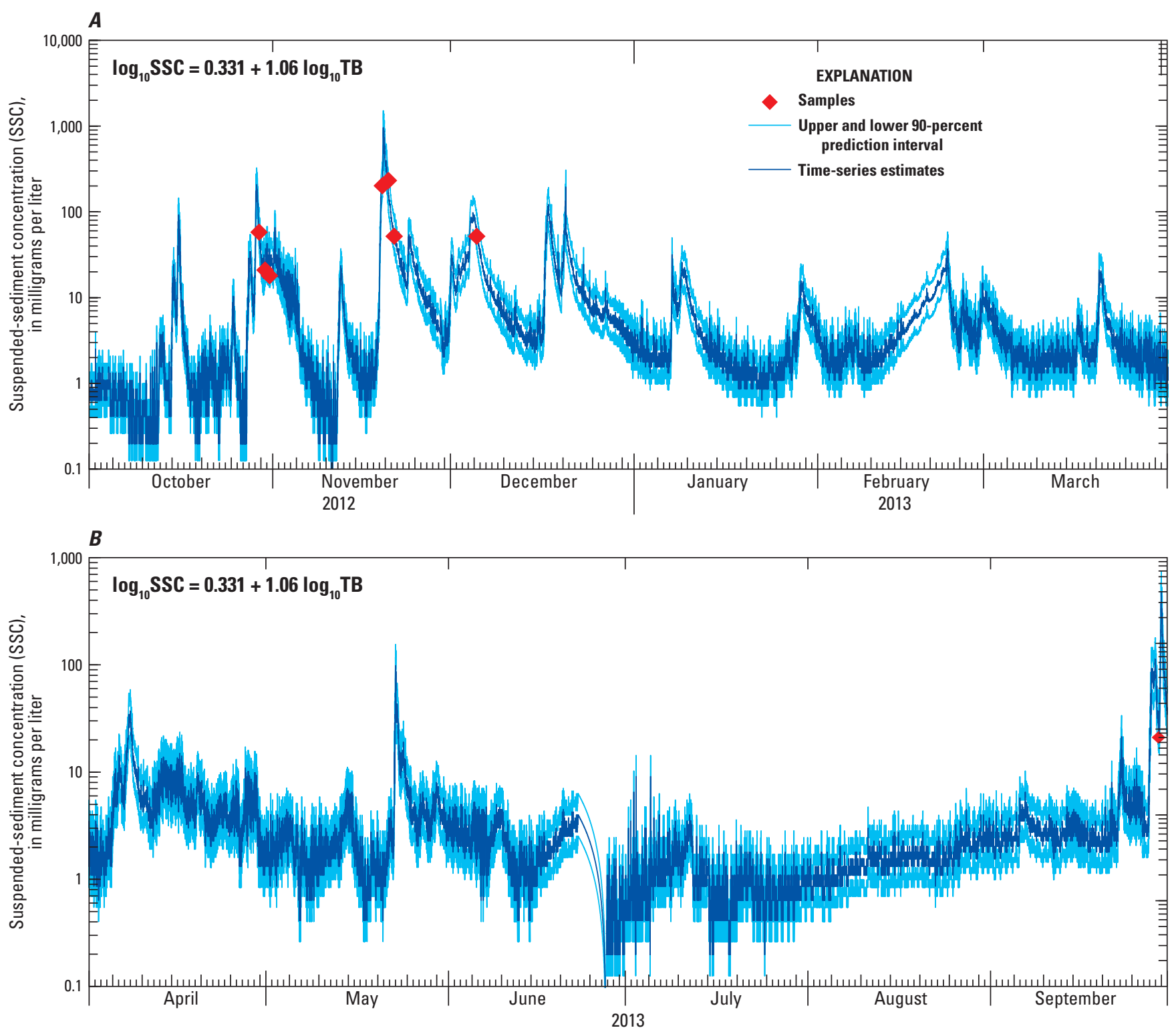

Figure B3. Suspended-sediment concentration (SSC) data, 90-percent prediction intervals, and sample data at the Trask River, northwestern Oregon, October 2012-March 2013 and April-September 2013. 

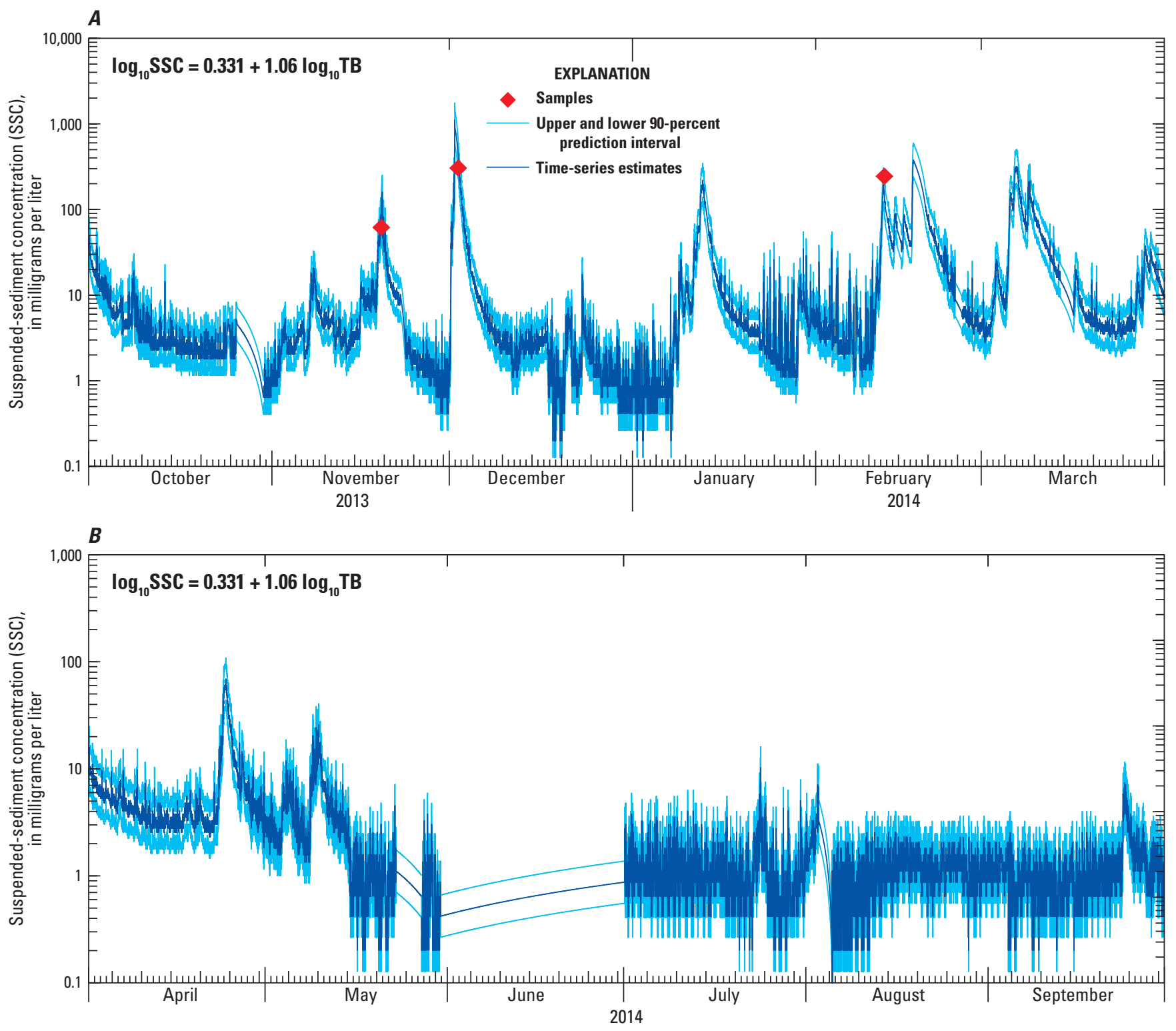

Figure B4. Suspended-sediment concentration (SSC) data, 90-percent prediction intervals, and sample data at the Trask River, northwestern Oregon, October 2013-March 2014 and April-September 2014. 
This page intentionally left blank. 


\section{Appendix C. Troubleshooting Instream Monitors}

During deployment, instrument sensors at both stations occasionally experienced temporary periods of data that did not meet established calibration specifications (Wagner and others, 2006). Measures were taken to minimize common problems of sensor deployment in high gradient mountain streams, including seasonal issues such as clogging by leaf litter (fig. C1) or accumulated fine sediment, biofouling, or sensor calibration drift.

During autumn, additional site visits were made by U.S. Geological Survey staff and volunteers to clean leaves and sediment buildup from the deployment pipes and instruments. Other chemical and mechanical solutions also were tested.
One of the simpler solutions was to increase the wiping interval for the optical sensors (turbidity and dissolved oxygen). This helped, but it did not eliminate the issues entirely. A non-toxic, anti-fouling nanopolymer C-spray (YSI, 2013) was used successfully for reducing the summer algal fouling issues, albeit for the short term (about 7-10 days). The most successful solution was the deployment of an aquarium pump attached to the instrument (fig. C2). The pump supplied a repetitive jet of water for 1 minute every 2 hours to clean the optical turbidity sensors. This worked extremely well, especially from July to October 2014.

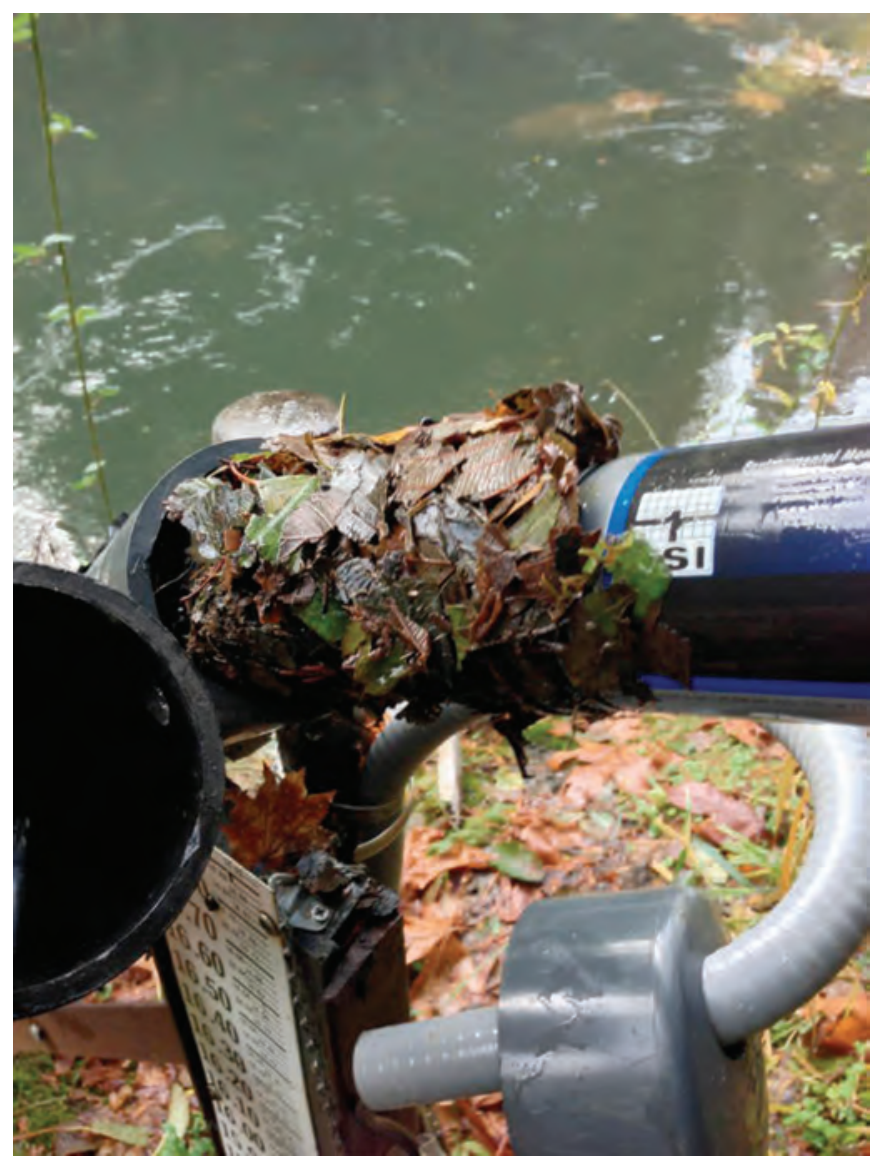

Figure C1. Siltation and leaf compaction clogging the pipe and instrumentation at the Trask River site, northwestern Oregon. Photograph by Mark Uhrich, U.S. Geological Survey, November 2012. 


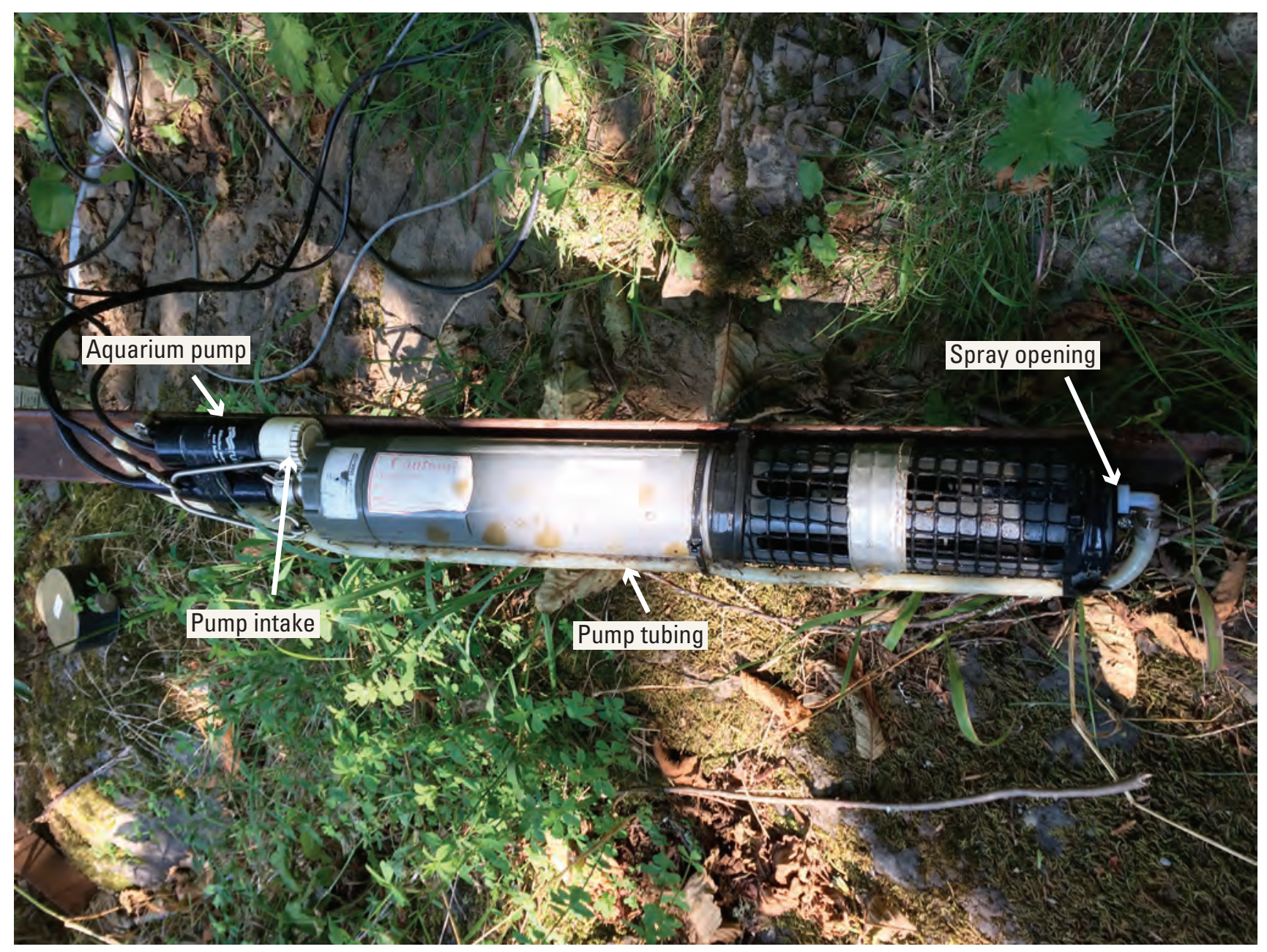

Figure C2. Aquarium pump installed on water-quality monitoring instrumentation at Trask River site, northwestern Oregon. The pump successfully eliminated bio-fouling issues during low-streamflow summer months. Photograph by Heather Bragg, U.S. Geological Survey, August 2014. 
Publishing support provided by the U.S. Geological Survey Science Publishing Network, Tacoma Publishing Service Center

For more information concerning the research in this report, contact the Director, Oregon Water Science Center

U.S. Geological Survey

2130 SW 5th Avenue

Portland, Oregon 97201

http://or.water.usgs.gov 


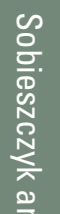

产

富

蛋

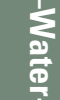

을

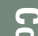

휼

总

के

富

旁

공

寨

를

赵

옹

锱

इ

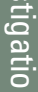

क

융

जั

임

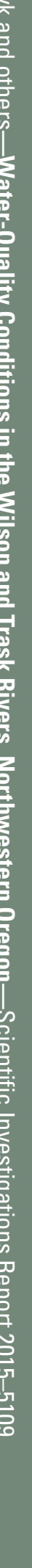

吾

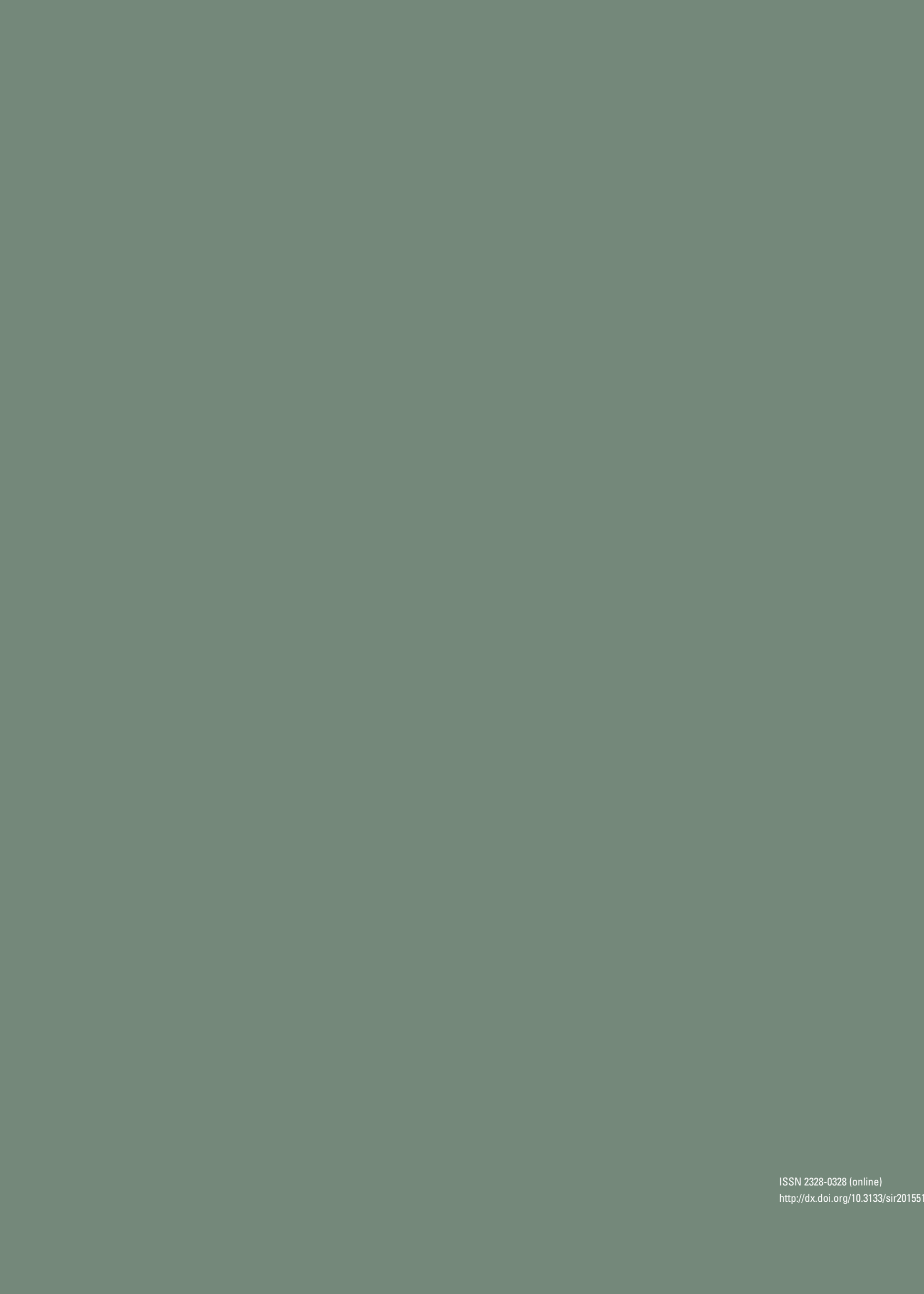

\author{
ISSN 2328-0328 (online)
http://dx.doi.org/10.3133/sir20155109 \\ ISSN 2328-0328 (online)
http://dx.doi.org/10.3133/sir20155109
}

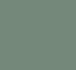

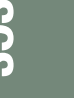
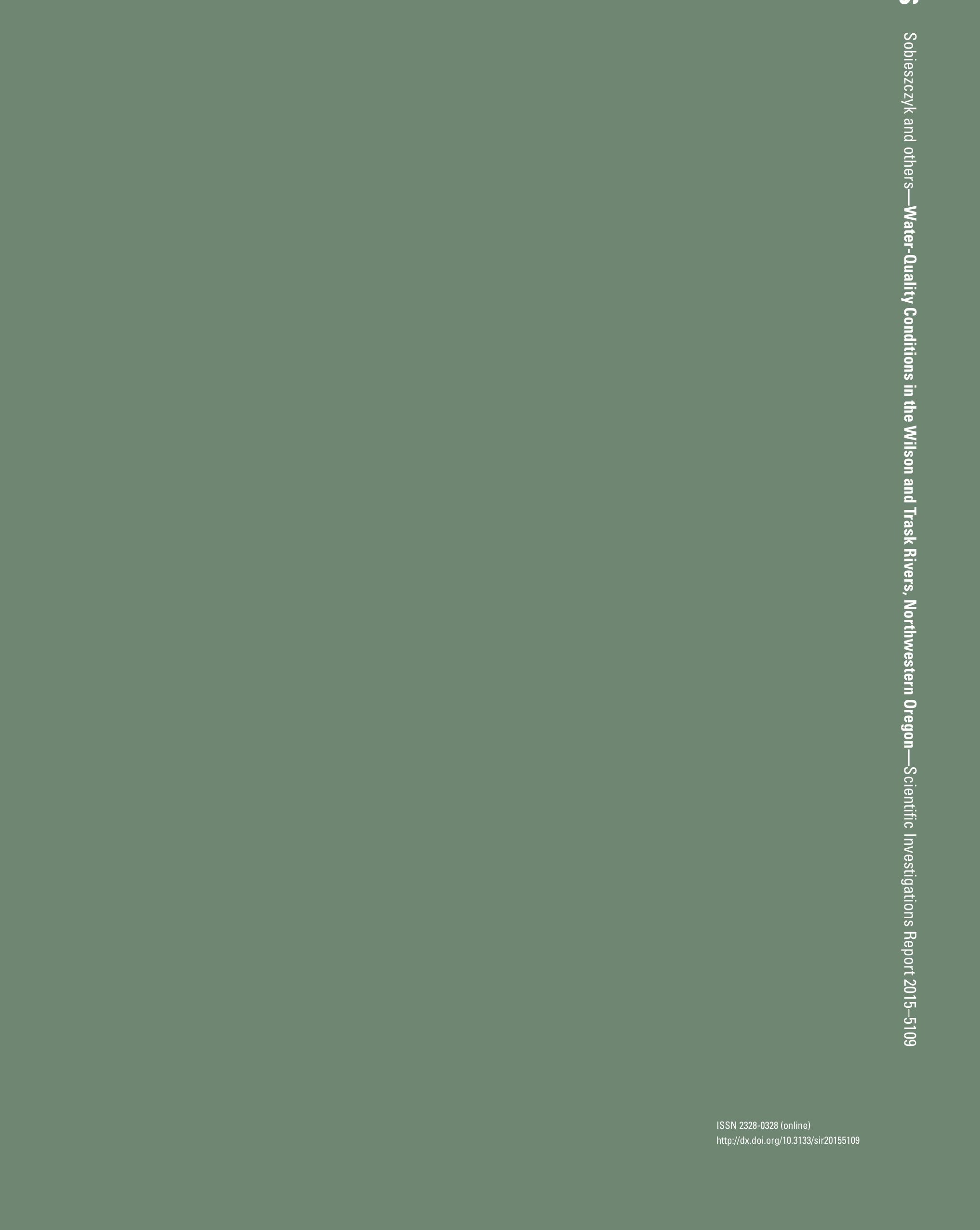